TAÍS APARECIDA MATOZO DE SOUZA

\title{
Envolvimento das Miosinas na Trans-Infecção de HIV-1 por Células Dendríticas
}

Dissertação apresentada ao Programa de Pós-Graduação em Imunologia do Instituto de Ciências Biomédicas da Universidade de São Paulo para obtenção do título de Mestre em Ciências.

Área de concentração: Imunologia

Orientadora: Bruna Cunha de Alencar Bargieri

Versão original 


\section{RESUMO}

SOUZA, TAM. Envolvimento das miosinas na trans-infecção do HIV-1 por células dendríticas. 2018. 90 p. Dissertação (Mestrado em Imunologia) - Instituto de Ciências Biomédicas, Universidade de São Paulo, São Paulo, 2018.

A infecção por HIV-1 leva a uma séria imunodeficiência causada principalmente pela depleção de linfócitos $T$ auxiliadores, a principal célula-alvo do vírus. Além dos linfócitos $T$ CD4, o HIV-1 também pode interagir e infectar macrófagos e células dendríticas (DCs). As DCs são resistentes à infecção pelo HIV-1, mas podem internalizar vírions em compartimentos e transferi-los para linfócitos $\mathrm{T} C D 4+$, em um processo chamado transinfecção. Para promover sua infecção, o HIV-1 subverte o citoesqueleto da actina da célula hospedeira em várias etapas de seu ciclo. Em DCs o citoesqueleto também é essencial para internalização do HIV-1 e formação dos compartimentos. Miosinas são proteínas motoras que interagem com filamentos de actina e estão envolvidas em diversos processos celulares, incluindo migração, transporte de moléculas, endocitose e reciclagem de componentes de lipid rafts. Apesar de existirem mais de 40 tipos de miosinas em humanos, apenas a miosina 2a foi estudada no contexto da trans-infecção. Por isso, nosso objetivo nesse trabalho foi estudar o papel das miosinas 1c e 1e na maturação de células dendríticas derivadas de monócitos (MDDCs) e na internalização de HIV-1 por estas células. Confirmamos por Real Time PCR a expressão de 10 miosinas em MDDCs de doadores saudáveis, depois verificamos que há regulação negativa da expressão do gene da miosina (myo1c) em MDDCs de pacientes HIV+. Analisamos a ativação das células em resposta ao lipopolissacarídeo (LPS) por meio da expressão de CD86 e HLA-DR em MDDCs silenciadas para myo1c e 1e. Não houve diferença na expressão dos marcadores de ativação em células silenciadas para miosina 1e (myo1e) em relação ao controle. No entanto, na maioria dos doadores testados, o silenciamento da myo1c interferiu com o aumento de expressão desses marcadores, indicando que a myo1c possa ter um papel na ativação celular por LPS. Ademais, a localização subcelular do HIV-1 em MDDCs silenciadas para myo1c e ativadas com LPS ficou mais próxima ao fenótipo de células imaturas. Contudo, não houve diferença na quantidade HIV-1 internalizado por MDDCs silenciadas para as miosinas 1c e 1e ou tratadas com um inibidor específico de miosinas do tipo 1. Estes resultados sugerem que a myo1c pode estar envolvida na ativação de células dendríticas e consequentemente alterar o mecanismo de internalização do HIV-1 por MDDCs.

Palavras-chave: Miosina. Células Dendríticas. HIV-1. Trans-infecção. 


\begin{abstract}
SOUZA, TAM. Involvement of myosins in HIV-1 trans-infection by dendritic cells. 2018. 90 p. Dissertação (Mestrado em Imunologia) - Instituto de Ciências Biomédicas, Universidade de São Paulo, São Paulo, 2018.
\end{abstract}

Infection by human immunodeficiency virus (HIV) leads to severe immunodeficiency caused by depletion of T helper cells, the main targets of the virus. Besides T CD4+ cells, HIV-1 can infect and interact with other immune cells, including dendritic cells and macrophages. Dendritic cells are resistant to HIV infection, however, they can bind and internalize HIV in compartments and then transfer the virus to CD4+ T cells in a process called trans-infection. To promote infection, HIV-1 subverts actin cytoskeleton of host cell at several points of its cycle. In DCs, cytoskeleton is also essential to HIV-1 internalization and compartment assembly. Myosins are motor proteins that can interact with actin and take part in several cellular processes, including migration, molecular trafficking, endocytosis and lipid raft recycling. Even though there are about 40 myosin types, only myosin $2 a$ has been investigated in trans-infection. Thus, our aim was to evaluate the role of myosins $1 \mathrm{c}$ and $1 \mathrm{e}$ in monocyte derived dendritic cell (MDDC) activation and HIV-1 internalization. We have validated the expression of 10 myosins in MDDCs by real-time PCR, and observed a down regulation of myosin 1c gene in HIV+ patients. We have evaluated cell activation in response to lipopolysaccharide (LPS) through CD86 and HLA-DR expression in myosin 1c and 1e knocked down MDDCs. There was no change in expression of activation markers in myosin 1e knocked down MDDCs compared with control cells. However, in most donors, myosin 1c knock down impaired the increase of activation markers following LPS treatment, suggesting that myosin 1c may play a role in cell activation by LPS. In addition, subcellular location of HIV-1 in MDDCs knocked down for myosin 1c and activated with LPS, was similar to immature cell phenotype. Nevertheless, we have not observed changes in the amount of HIV-1 internalized by myosin 1c or 1e knocked down MDDCs or in MDDCs treated with myosin I inhibitor. These data suggest that myosin 1c may play a role in MDDC activation and therefore alter the mechanism of HIV-1 internalization by MDDCs.

Keywords: Myosin. Dendritic cell. HIV-1. Trans-infection 


\section{INTRODUÇÃO}

\subsection{HIV}

Desde seu aparecimento no início dos anos 1980, o vírus da imunodeficiência humana (HIV) já infectou mais de 85 milhões de pessoas em todo o mundo (UNAIDS). No Brasil, o HIV já infectou mais de 800 mil pessoas e apresentou incidência média de 40 mil casos por ano nos últimos 5 anos. Estima-se que mais de 37 milhões pessoas vivem com HIVIAIDS no mundo (DEEKS et al, 2015). Apesar dos esforços na prevenção da infecção por HIV-1, têm-se observado um aumento na incidência da infecção em alguns grupos no Brasil (Ministério da Saúde).

O HIV é um lentivírus da família Retroviridae que infecta e depleta linfócitos T CD4+ humanos, levando à síndrome da imunodeficiência adquirida (AIDS). (DEEKS et al, 2015). Dois tipos de HIV foram identificados, HIV-1 e HIV-2, sendo o HIV-1 derivado do vírus da imunodeficiência símia de chimpanzés e gorilas, e o HIV-2 derivado do SIV de macacos Cercocebus atys (SHARP et al., 2010). Dentre os diferentes grupos de HIV-1, cada um resultante de um evento de transmissão de macacos para humanos, o grupo $\mathrm{M}$ é o maior responsável pela pandemia mundial de HIVIAIDS. Já o HIV-2 é mais prevalente a oeste do continente africano, e leva a uma doença de progressão mais lenta do que o HIV-1 (DEEKS et al., 2015).

A transmissão do vírus ocorre pelo contato com fluidos corporais de uma pessoa infectada. A infecção pode ocorrer de forma horizontal (contato entre mucosas durante relações sexuais ou inoculação percutânea) ou vertical (durante o parto ou amamentação - BONGERTZ, 2001; HANSASUTA; ROWLAND-JONES, 2001) .

Diversas características do HIV-1 levaram ao relativo "sucesso" da pandemia. Após o primeiro mês, o sistema imune consegue controlar a viremia e o hospedeiro pode permanecer sem sintomas por longos períodos de tempo. Isso aumenta a disseminação do vírus na população e dificulta o reconhecimento da origem da infecção. A alta taxa de mutação do HIV-1 leva a mudanças nos antígenos do vírus, de modo que os anticorpos produzidos pelo hospedeiro e linfócitos específicos para os antígenos do HIV se tornam ineficientes (DEEKS, 2015). É também por essa razão que o desenvolvimento de uma vacina ainda não foi alcançado. 
Os tratamentos para HIVIAIDS começaram em 1986 com a zidovudina (AZT) e, desde a implantação da terapia antirretroviral de alta eficiência (do inglês highly active antiretroviral therapy, HAART), a sobrevida das pessoas que vivem com HIV aumentou. A HAART consiste em três ou mais drogas que podem agir na entrada, retrotranscrição, integração ou maturação da partícula viral. São capazes de diminuir a viremia para níveis indetectáveis e consequentemente restaurar a frequência de linfócitos T CD4+ no hospedeiro (BARRÉ-SINOUSSI; ROSS; DELFRAISSY, 2013). Embora os tratamentos tenham melhorado significativamente a vida destas pessoas, ainda não há cura para a infecção ou previsão do desenvolvimento de uma vacina efetiva contra o vírus.

Além do escape pelas mutações, o HIV-1 também pode induzir uma infecção latente, isto é, em algumas células, o vírus integra no genoma do hospedeiro, mas não é expresso, fazendo com que células infectadas fiquem invisíveis ao sistema imune do hospedeiro e se tornem reservatórios virais (KANDATHIL; SUGAWARA; BALAGOPAL, 2016). Como as drogas existentes atuam prevenindo novas infecções mas não eliminam células já infectadas, a terapia antirretroviral também não é capaz de agir sobre o HIV latente. Os reservatórios virais são, portanto, o principal obstáculo para a cura do HIVIAIDS, visto que os são responsáveis pela recrudescência do vírus após a interrupção da HAART (HONG; MELLORS et al., 2016).

\subsubsection{Proteínas virais}

O genoma do HIV-1 tem em torno de $9 \mathrm{~kb}$ e as proteínas codificadas por ele são dividas em proteínas estruturais, reguladoras e acessórias. Entre as proteínas estruturais estão as proteínas do envelope, (codificadas pelo gene Env) gp120 e gp41; as proteínas codificadas pelo gene gag, que são traduzidas no percursor p55 que após o brotamento é clivado em 4 proteínas: p17, que forma a matriz viral; p24, que forma o capsídeo; p7, que forma o nucleocapsídeo; e p6, que é necessária para o brotamento. Por fim, há as proteínas estruturais codificadas pelo gene pol, que incluem as enzimas integrase, transcriptase reversa, protease e RNAse H (HOPE, 2000). 
As proteínas reguladoras incluem a tat, que promove a elongação inicial para a transcrição do HIV (SODROSKI et al., 1985), e a rev, que exporta o RNA que não sofreu splicing para o citoplasma (FISCHER et al., 1995).

O HIV-1 possui quatro proteínas acessórias (Vpr, Vpu, Nef e Vif), que são chamadas assim pois são parcialmente dispensáveis in vitro, uma vez que suas funções estão mais relacionadas ao escape da resposta antiviral do hospedeiro (MALIM e EMERNAN, 2008).

\subsubsection{Ciclo viral}

Durante seu ciclo, o HIV-1 se utiliza de diversas maquinarias e proteínas do hospedeiro para o sucesso da infecção e disseminação, como mostrado na figura 1. O HIV-1 tem um ciclo complexo a nível intracelular que se inicia com a ligação da glicoproteína gp120, do envelope do vírus, ao receptor CD4. Após essa ligação há uma mudança conformacional nas proteínas gp120 que leva à exposição da região variável 3 (V3), que se liga ao correceptor CXCR4 (C-X-C chemokine receptor type 4) ou CCR5 (C-C receptor de quimiocina tipo 5). Após a estabilização dessa ligação, os domínios da gp41 formam uma estrutura com seis hélices que promovem a fusão do envelope viral à membrana da célula-alvo (WILEN et al., 2012).

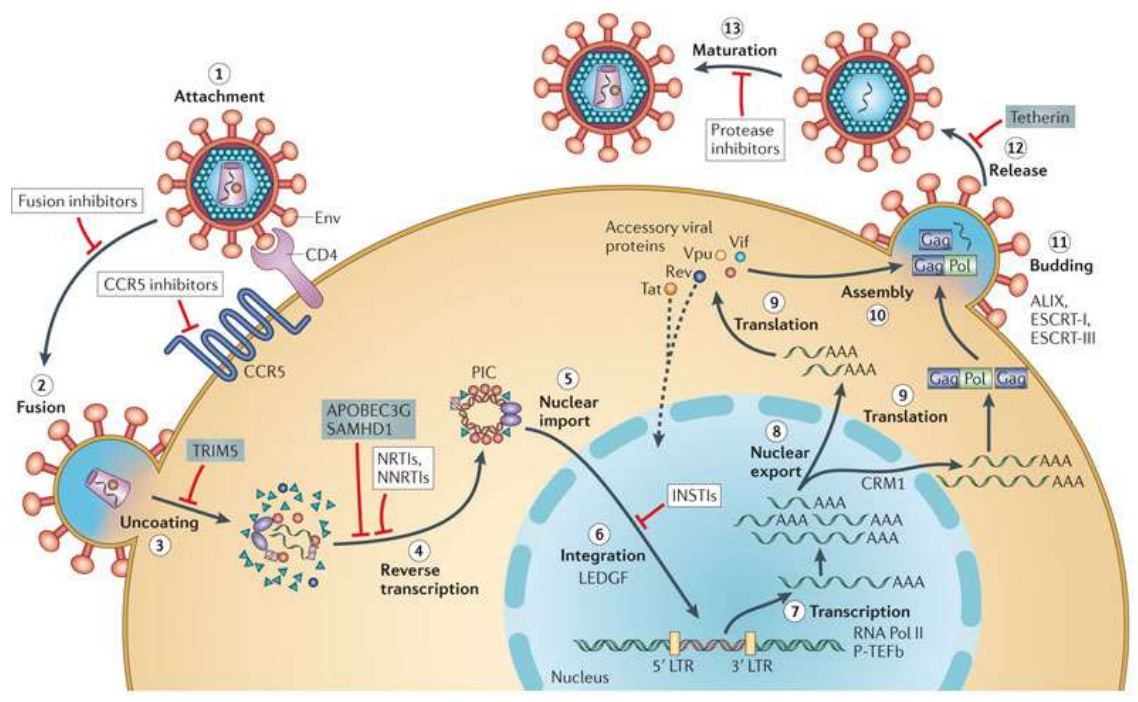

Nature Reviews | Microbiology

Figura 1. Ciclo do HIV-1. O envelope dos vírions de HIV-1 interage com CD4 e CCR5 ou CXCR4 na membrana da célula e promove fusão, de modo a liberar o capsídeo no citoplasma da célula alvo. O HIV-1 realiza a transcrição reversa de seu RNA e é transportado até o espaço perinuclear, onde é importado para o núcleo e seu material 
genético se integra ao genoma do hospedeiro. Começa então a transcrição do genoma viral e tradução de suas proteínas, que migram até a membrana da célula do hospedeiro onde a partícula viral é montada. Após a montagem, a partícula sofre o brotamento, ficando livre da célula do hospedeiro e passando pela maturação. Adaptado de Engelman; CHEREPANOV, 2013.

Os processos subsequentes à entrada do capsídeo viral no citoplasma até a integração do genoma viral ainda não estão completamente elucidados. Sabe-se que há a desestabilização do capsídeo viral, processo que aparentemente depende de diversas proteínas, incluindo a integrase do HIV-1 (BRIONES et al., 2010) e a ciclofilina A (CypA - LUBAN et al., 1993; ) do hospedeiro. O momento em que ocorre a desestabilização, entretanto, ainda não está claro. Em células da imunidade inata, a proteína CypA se associa ao capsídeo viral no citoplasma e dificulta o reconhecimento dos ácidos nucléicos virais por receptores de reconhecimento de padrões (PRRs) da célula hospedeira (ALTFELD; GALE, 2015).

Após a desestabilização do capsídeo, o RNA viral é retro transcrito em cDNA pela transcriptase reversa (RT). A RT utiliza como primer o tRNA Lys3 do hospedeiro, que é complementar à região 5' do RNA viral (HU; STEPHEN, 2012). Além do tRNA, o pool intracelular de dNTP do hospedeiro também é necessário para a transcrição reversa. A RNAse $\mathrm{H}$ do HIV-1 degrada o RNA viral, e o cDNA permanece em associação com a matriz, nucleocapsídeo, integrase e Vpr, formando o PIC (complexo pré-integração - JAYAPPA et al., 2012).

Os retrovírus, em geral, não são capazes de infectar células que não estão em divisão, uma vez que seu material genético não é importado ao núcleo. No entanto, descobriu-se que os lentivírus possuem mecanismos que os possibilita infectar células que não estão dividindo (LEWIS et al., 1992). Vários modelos foram propostos para o processo, e ainda existem muitas contradições nos estudos, portanto não se sabe ao certo quais proteínas estariam envolvidas diretamente. Estudos mostram que a proteína matriz viral possui um sinal de localização nuclear que permitiria seu reconhecimento pelas importinas $(\operatorname{Imp}) \alpha$ e $\beta$, que poderiam facilitar sua importação para o núcleo. A proteína acessória do HIV-1, Vpr, também pode estar associada à importação do complexo ao núcleo, visto que é importada mesmo na ausência da matriz e de outras proteínas virais. A integrase também parece ser necessária para o processo. No entanto, a importação para o núcleo seguiria uma via não canônica, dependente de imp7 e transportina 3, ou ainda, uma 
importação mediada diretamente pela interação da integrase com os poros nucleares (CAMPBELL; HOPE, 2015).

Uma vez dentro do núcleo, o cDNA é integrado ao genoma pela integrase, com o auxílio de proteínas do hospedeiro, e se inicia a transcrição do DNA. O HIV-1 possui dois long terminal repeats (LTR), um na região 5' e outro na região 3'. O LTR na porção 5' age como promotor do vírus e é sitio de ligação de diversos fatores de transcrição, incluindo NF-kB (nuclear factor kB). No início, são gerados, em sua maioria, pequenos transcritos e poucos transcritos completos, mas que são suficientes para a expressão da proteína Tat. A Tat é importada para o núcleo após sua tradução e interage com o sítio TAR do RNA nascente. Essa interação promove a transcrição completa do DNA viral por meio da elongação (FEINBERG et al, 1991; CLARK et al., 2017).

Uma das estratégias propostas para a "eliminação" dos reservatórios virais consiste no uso do inibidor de Tat, didehydro-Cortistatin $A$, que impede que 0 reservatório seja reativado após a interrupção da HAART (KESSING et al., 2017).

Após a transcrição, mRNAs spliceados e RNAs genômicos (gRNAs) nãospliceados são exportados para o citoplasma (estes últimos com auxílio da proteína Rev), e são utilizados para a tradução das proteínas virais tanto no citoplasma quanto no retículo endoplasmático. O gRNA não spliceado é utilizado como material genético das novas partículas virais (HOPE, 2000).

Oligômeros das proteínas Gag e Gag-pol iniciam a montagem da partícula viral em microdomínios resistentes a detergentes da membrana plasmática. O principal mecanismo de ancoragem da Gag à membrana é pelo recrutamento e interação da porção amino-terminal miristoilada da matriz da Gag com $\mathrm{Pl}_{(4,5)} \mathrm{P} 2$ (fosfatidil inositol $(4,5)$ bifosfato) na membrana. Os trímeros de envelope e as demais proteínas da partícula viral chegam à membrana e interagem com diversas porções de Gag ou Gag-Pol, assim como as duas fitas de RNA viral dimerizadas (SUNDQUIST e KRÄUSSLICH, 2012). A ordem e o mecanismo de recrutamento desses fatores não foram completamente descritos.

Por fim, o motivo PTAP da proteína p6 da Gag se liga a TSG101 (tumor susceptibility gene 101) e o motivo YPXL se liga a ALIX. TSG101 e ALIX fazem parte 
do complexo ESCRT (endosomal sorting complexes required for transport), que culmina com o recrutamento de proteínas do complexo ESCRT-III. Estas, por sua vez, medeiam o fechamento da membrana no processo de brotamento e liberação da partícula viral (SUNDQUIST e KRÄUSSLICH, 2012).

\subsubsection{Proteínas acessórias virais e fatores de restrição}

As células humanas expressam uma série de fatores de restrição que podem limitar a replicação do HIV (Figura 1). Por exemplo, a proteína BST-2 (bone marrow stromal cell antigen 2) está presente nos lipid rafts da membrana plasmática (local preferencial para o brotamento do HIV-1 - KUPZIG et al., 2003; DING et al) e atua como uma âncora, impedindo a liberação de partículas virais após o brotamento (VAN DAMME et al., 2008; GOFFNET et al, 2009). A proteína acessória Vpu do HIV1 pode interagir diretamente com BST-2 e reduzir sua expressão nos locais de brotamento viral (ARIAS et al., 2012). Além disso, a Vpu também é responsável por diminuir a expressão de CD4 na superfície das células infectadas (WILEY et al., 1992).

A proteína viral Vif bloqueia a incorporação à partícula viral do fator de restrição Apolipoprotein B MRNA Editing Enzyme Catalytic Subunit $3 G$ (APOBEC3G), que causa mutações no genoma viral, levando à produção de proteínas não funcionais e insucesso da infecção (SIMON et al., 2015).

Nef é a única proteína acessória cuja importância pôde ser verificada in vivo. Pessoas que adquiriram uma cepa de HIV-1 deficiente de Nef ficaram anos sem desenvolver sintomas da AIDS e uma delas apresentava carga viral indetectável (LEARMONT et al., 1999). Muitas funções foram atribuídas à Nef, entre elas a regulação negativa de algumas proteínas de superfície (incluindo CD4 e MHC I (Complexo principal de histocompatibilidade) - PIGUET et al., 1999), e regulação da ativação e migração de células T e macrófagos (MANGINO et al., 2011; VÉROLLET et al., 2015). Recentemente, foram descritos mais dois fatores de restrição ao HIV-1, SERINC3 e SERINC5, que na ausência de Nef são incorporados aos vírions e impedem a infecção ainda nos primeiros estágios do ciclo (USAMI et al., 2015; ROSA et al., 2015). 
Outro fator de restrição, o SAM domain and HD domain-containing protein (SAMHD1), é expresso principalmente em células não-replicativas incluindo macrófagos derivados de monócitos (MDMs) e DCs (LAGUETTE et al., 2011). SAMHD1 é uma enzima citoplasmática que possui em sua estrutura um domínio HD com atividade de nucleasse (GOLDSTONE et al., 2011). O SAMHD1 cliva dNTPs disponíveis na célula, que são necessários para a retrotranscrição do HIV-1 (LAHOUASSA et al., 2012) . Esse fator está associado à baixa susceptibilidade à infecção por HIV-1 de células dendríticas (DCs). Outros lentivírus como o SIV e o HIV-2 possuem uma proteína chamada $V p x$ ao invés da $V p u$, que é capaz de diminuir os níveis de SAMHD1 em DCs ou macrófagos, deixando-os mais susceptíveis à infecção (GOUJON et al., 2007).

O Tripartite motif-containing protein 5 (TRIM5 $\alpha$ ) até recentemente era considerado um fator de restrição do HIV apenas em células de primatas nãohumanos, nas quais é capaz de interagir com o capsídeo viral do HIV-1 e leva-lo à degradação pelo proteassoma (STREMLAU et al., 2004; SASTRI; CAMPBELL, 2011). No entanto, esse efeito não era observado com o TRIM5a humano. Recentemente, o TRIM5 $\alpha$ foi associado ao processo de degradação do HIV-1 nos grânulos de Birbeck de células de Langerhans (RIBEIRO et al., 2016).

Em alguns tipos celulares, a proteína Interferon-induced GTP-binding protein Mx2 (MxB) pode inibir a infecção do HIV-1 por mecanismos ainda desconhecidos, mas possivelmente relacionados com o transporte do PIC ao núcleo celular (LIU et al, 2013; MATREYEK et al., 2014).

\subsection{Células Dendríticas}

Linfócitos T CD4+ são o principal alvo do HIV-1, e, portanto, a maior parte dos estudos são focados no ciclo dentro dessas células. Entretanto, quaisquer células que expressem CD4 e um dos correceptores do vírus também são passíveis de infecção ou interação com o vírus. Entre essas células estão os macrófagos, monócitos e as DCs (GARTNER et al, 1986; MANN et al, 1990; WEINBERG et al, 1991; CAMERON et al 1992A; POPE et al, 1994; GRANELLI-PIPPERMO et al, 1996) que possuem particularidades na infecção por HIV-1. 
Estudos recentes têm demonstrado uma importância cada vez maior das células mielóides na infecção. Ensaios com camundongos NOD/SCID repopulados com células CD34+ humanas, também chamados camundongos humanizados, demonstraram que células mielóides são capazes de sustentar a infecção por HIV-1 na ausência de células T e Natural Killer (NK - HONEYCUTT et al., 2017).

No contexto da infecção por HIV-1, as DCs possuem um papel ambíguo. Elas podem ser produtivamente infectadas pelo vírus e mediar a trans-infecção, no entanto, são as principais responsáveis pela apresentação antigênica de epítopos do HIV-1 para ativação do sistema imune contra o vírus, além de produzirem intérferons do tipo I (IFN I), que levam a célula a um estado antiviral que previne a infecção (AHMED et al, 2015).

DCs são peças chave na imunidade, uma vez que fazem a ponte entre a imunidade inata e adaptativa, apresentando antígenos proteicos a linfócitos $T$ naïve (BANCHEREAU et al, 1998). Além disso, essas células apresentam importante resposta antiviral (BARCHET et al, 2005; KIRSCHNER et al, 2008). Apesar de pertencentes ao sistema mononuclear fagocítico, as DCs podem ser facilmente diferenciadas de macrófagos e monócitos por sua alta expressão de moléculas do MHC de classe II, capacidade de migração dos tecidos até os linfonodos por vasos linfáticos aferentes, e apresentação antigênica aos linfócitos T (HANIFFA et al, 2013).

O estado de maturação das DCs é um fator importante nas relações DC-HIV, pois grande parte do estado antiviral que as DCs adquirem após a maturação dependente de IFN se deve aos ISGs (interferon stimulated genes - SCHOGGINS; RICE, 2011). A transcrição desses genes tem início/aumento após estimulo de IFNs do tipo I (alfa e beta) ou do tipo III, que podem ser advindos de via autócrina ou parácrina. Após a ligação ao receptor de IFN tipo I (IFNAR) em DCs, STAT1 e STAT2 são fosforiladas e formam um complexo com IRF9, que então ativa a transcrição dos mais de 100 ISGs (Revisado por ALTFIELD e GALE, 2015).

Dentre os genes estimulados, alguns são responsáveis pela detecção do HIV. O IFI16 (intérferon inducible protein 16) é uma proteína da família PYHIN presente no núcleo e no citosol celular, capaz de reconhecer produtos da transcrição reversa e ativar as vias de intérferon por meio de STING (ISHIKAWA; BARBER, 2009; 
JAKOBSEN et al., 2013) e TBK1 (TANAKA; CHEN, 2012), que ativam interferon regulatory factor (IRF) IRF7 e IRF3. IFI16 pode ser ativado por DNA dupla-fita (dsDNA) exógeno e endógeno (no caso células apoptóticas) por meio dos dois domínios HIN em sua estrutura (UNTERHOLZNER et al., 2010; JIN et al., 2012). Além de IFI16, o cGAS também ativa STING em resposta à ligação a dsDNA de alguns retrovírus e libera GMP cíclico (GMP-AMP), ambos capazes de recrutar STING (GAO et al., 2014). Outros ISGs também incluem os fatores de restrição SAMHD1 e MX2, descritos acima, além de uma série de proteínas cujas funções não são ainda compreendidas.

Desde sua descoberta, vários subtipos de DCs foram descritos e várias classificações foram propostas. É importante a elucidação das características de cada subtipo de DC, visto que cada um deles pode desempenhar um papel diferente durante a infecção por HIV-1 (SANDERS et al., 2012).

As DCs podem ser classificadas como: migratórias (presentes no sangue), que expressam altos níveis de MHC II e baixos níveis de CD11c; e residentes, que são encontradas nos tecidos e expressam altos níveis de CD11c e baixos níveis de MHC II (SATO; FUJITA, 2007). Acredita-se que as DCs migratórias sejam na verdade percursoras das DCs presentes nos tecidos (LIU et al., 2001; BRETON et al., 2016).

Entre as DCs teciduais encontram-se as células de Langerhans, que são capazes de interagir com HIV-1 e degrada-lo em seus grânulos de Birbeck (WITTE et al., 2007; RIBEIRO et al., 2016). No entanto, as células de Langerhans também podem ser infectadas se expostas a altas concentrações de HIV-1 (SUGAYA et al., 2004). Outros subtipos de DCs dermais, como as células CD14+ e CD1a+ podem transmitir o vírus (AHMED et al., 2015).

Foram identificados três subtipos de DCs migratórias: dois deles são DCs de origem mielóide (mDC); o terceiro, chamado de DCs plasmocitóides ( $\mathrm{pDC}$ ), não tem origem definida. mDCs possuem os marcadores de percursores mieloides CD11C, MHC classe II e CD4, e não expressam CD14 ou marcadores de linhagem linfoide como CD3, B220 e CD56 (MERAD et al., 2013).

\subsubsection{Células dendríticas mielóides (mDCs)}


Um dos subtipos de mDC pode ser discernido do outro por sua alta expressão de CD141 (BDCA-3) e CLEC9A e, apesar de não possuírem uma gama muito grande de receptores PRRs, foi descrito que essas células são especializadas na apresentação cruzada de antígenos a linfócitos T CD8+ (JONGBLOED et al, 2010; HANIFFA et al., 2012). O segundo subtipo de mDC pode ser distinguido do outro pela expressão de CD1c (BDCA-1) e, diferente das células CD141+, possui uma gama maior de PRRs, incluindo os toll like receptors (TLR)1-10 e Dectina-1 e 2 (LUNDBERG et al, 2014).

As DCs mielóides CD141+ também são resistentes à fusão viral de vírus envelopados. A resistência é conferida pela alta expressão de Rab15 nos endossomos destes subtipos, mas o mecanismo exato ainda está sendo investigado. As DCs 141+ expressam TLR7 e TLR8, que podem reconhecer o RNA viral e induzir a produção de IFN. O papel das DCs CD141+ ainda não foi elucidado in vivo, no entanto, estudos sugerem que a apresentação cruzada promovida pelas mesmas é necessária para melhor indução da resposta de linfócitos T (SILVIN et al., 2017).

DCs CD1c+ são mais permissivas à infecção por HIV-1 em comparação às DCs CD141+, mas ainda possuem certa resistência ao HIV-1 que é conferida pela expressão de SAMHD1 (SILVIN et al., 2017).

O reconhecimento do HIV-1 também leva à ativação destas células e produção de IFN do tipo I com expressão de ISGs. No entanto, o reconhecimento do vírus é feito principalmente por cGAS com pouca atuação dos TLRs (SILVIN et al., 2017).

\subsubsection{Células dendríticas plasmocitóides ( $p D C s$ )}

Assim como as mDCS, as pDCs ativadas também podem ativar linfócitos $\mathrm{T}$. No entanto, sua principal característica é a produção de grandes quantidades de interferon do tipo I. pDCs não tem origem definida e, diferentemente dos outros subtipos, apresentam um fator de transcrição mestre, TCF4, que facilita sua identificação, juntamente aos seus marcadores específicos CD123, CD303 e CD304 (HANIFFA et al, 2013; REIZIS et al, 2011). 
Em um estudo publicado em um modelo de infecção de HIV-1 em primatas não humanos, foi demonstrado que as $\mathrm{pDCs}$ são recrutadas logo no início para o local da infecção e produzem quimiocinas que recrutam linfócitos T CD4+, o que acarreta na potencialização da infecção no animal (O'BRIEN et al., 2013). Apesar do papel patogênico no inicio da infecção, as pDCs são as principais produtoras de IFN do tipo I, que por sua vez é capaz de induzir um estado antiviral na célula e impedir a infecção (SOPER et al., 2017).

As pDCs são resistentes à infecção por HIV-1, mas são capazes de endocitar o HIV-1 e reconhece-lo por TLR7, que inicia a ativação de uma cascata de sinalização que leva à ativação da célula e produção de IFN- $\alpha$ (BEIGNON et al., 2005). O mecanismo de resistência ao HIV-1 das pDCs ainda é discutido, mas um trabalho recente demonstra que o vírus é incapaz de realizar a fusão e liberar o capsídeo no citoplasma (SILVIN et al., 2017). No entanto, alguns autores associam a resistência à presença de SAMHD1 assim como é descrito para DCs CD1C+ (BLOCH et al.,2014).

\subsubsection{Células dendríticas derivadas de monócitos (MDDCs)}

Um estudo demonstrou que monócitos poderiam dar a origem a DCs em linfonodos (RANDOLPH et al, 1999), e mais tarde o mesmo fenômeno foi demonstrado em modelo murino de inflamação (LE BORGNE et al., 2006). Assim como DCs mielóides, as células dendríticas derivadas de monócitos (Monocyte Derived Dendritic Cells - MDDCs) são capazes de apresentar antígenos para linfócitos T CD4+, estimulando principalmente respostas do tipo Th1 (LEÓN et al, 2007). Descobriu-se também que MDDCs poderiam ser diferenciadas em DCs in vitro na presença de GM-CSF e IL-4 (SALLUSTO; LANZAVWCCHIA, 1994; CHAPUIS et al., 1998; GIESELER et al., 1998), e, desde então, essas células têm sido usadas como modelo de DCs em muitos estudos.

Em humanos são encontrados dois subtipos de monócitos, CD14 high, também conhecidos como monócitos clássicos, e CD14low $\mathrm{CD} 16^{+}$, monócitos não clássicos (HANIFFA, et al., 2015). Acredita-se que os monócitos CD16+ possam ser percussores de DCs, visto que, em um modelo in vitro de trans-migração endotelial, essas células têm uma tendência à diferenciação em DCs (RANDOLPH et al, 2002). 
No entanto, na diferenciação in vitro com GM-CSF (Granulocyte-macrophage colonystimulating factor) e IL-4 (interleucina), monócitos CD16+ não se diferenciaram tão bem em MDDCs como os monócitos clássicos (BOYETTE et al., 2017). Similarmente às células dendríticas encontradas nos tecidos, as MDDCs também sofrem maturação após estímulo com LPS ou citocinas (WU e KEWELRAMANI, 2006; IZQUIERDO-USEROS et al, 2007).

MDDCs possuem importante contribuição no reconhecimento do vírus HIV e apresentação antigênica para subsequente indução da imunidade celular e humoral (MORIS et al ., 2004 e 2006; RODRIGUEZ-PLATA et al., 2012). Todavia, também podem contribuir para a patogenia, uma vez que uma pequena porcentagem dessas células pode ser produtivamente infectada pelo HIV-1 (SMED-SÖRENSEN et al, 2005). Elas possuem níveis mais baixos de SAMDH1 em comparação às mDCs, mas que ainda conferem resistência à infecção por HIV-1 (ZHANG et al., 2014; SILVIN et al., 2017). No contexto do HIV-1, MDDCs parecem estar mais relacionadas às $\mathrm{DCs} C D 1 \mathrm{C}^{+}$, já que o HIV-1 pode fundir em sua membrana, também realizam trans-infecção e o reconhecimento do vírus acontece pela via de cGAS (GAO et al., 2013).

\subsection{Trans-infecção}

DCs têm sido implicadas na infecção pelo HIV desde 1992 quando, em ensaios in vitro, descobriu-se que podiam potencializar a infecção em linfócitos $T$ CD4+ por meio de um fenômeno conhecido hoje como trans-infecção (CAMERON et al,. 1992b). A trans-infecção é o processo pelo qual DCs não infectadas transportam vírions do HIV-1, e os transferem para linfócitos T CD4, potencializando a infecção dos linfócitos (Figura 2 - MCDONALD, 2010). Apesar de sua contribuição para a patogenia da infecção in vivo ainda não estar bem elucidada, acredita-se que a trans-infecção mediada por DCs tenha importante papel na disseminação sistêmica do HIV-1 (WU; KEWALRAMANI, 2006; TURVILLE et al., 2006), levando o vírus do local de entrada para linfonodos, onde há grande concentrações linfócitos T CD4. 


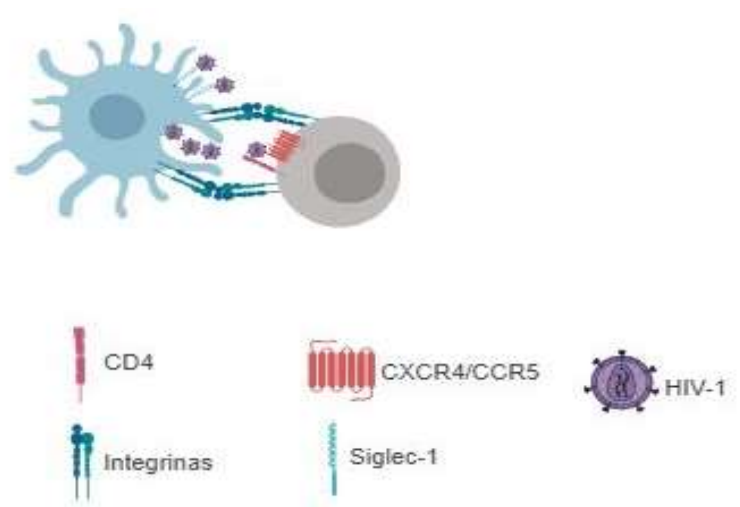

Figura 2. Trans-infecção de HIV-1 por células dendríticas. As DCs interagem com HIV-1 por meio de seus receptores e podem internaliza-lo em compartimentos ligados à membrana. Mais tarde, quando em contato linfócitos TCD4+, realizam uma sinapse com linfócitos $\mathrm{T}$, por meio da interação de integrinas expressas na membrana de ambas as células e os linfócitos T acabam por ser infectados pelo vírus presente nas DCs.

As DCs interagem com HIV-1 por meio de receptores na membrana plasmática e podem endocitar o vírus ou internaliza-lo em compartimentos ligados à membrana (GEIJTENBEEK et al., 2000; YU et al., 2008; IZQUIERDO-USEROS et al., 2012b; YU et al., 2015).

Em 2002 um grupo descreveu DC-SIGN como responsável pela internalização do HIV para o processo de trans-infecção por DCs. Em tal modelo, a gp120 do HIV se ligava ao DC-SIGN, levando à internalização do vírus (GEIJTENBEEK et al., 2000). No entanto, trabalhos posteriores mostraram que MDDCs depletadas de DC-SIGN ainda eram capazes de trans-infectar, sugerindo que outros receptores estavam envolvidos na trans-infecção (GUMMULURU et al., 2003; BOGGIANO et al., 2007; TURVILLE et al., 2002).

Em 2012, Izquierdo-Useros e colaboradores mostraram que os resíduos de acido siálico em gangliosídeos, incorporados no envelope lipídico do HIV-1 durante o brotamento, mais especificamente GM1 e GM3, eram os ligantes necessários para a captura do vírus por DCs maduras (IZQUIERDO-USEROS, 2012a). Mais tarde no mesmo ano este grupo também identificou o CD169 (ou Siglec-1) como o principal receptor responsável pela internalização do HIV em DCs maduras (IZQUIERDOUSEROS et al., 2012b).

O CD169 é um receptor transmembrânico tipo I e sua estrutura compreende 17 domínios imunoglobulina extracelulares, que podem se ligar aos ácidos siálicos 
com a ligação glicosídica $\alpha 2-3$ ou $\alpha 2-6$. Ele é expresso constitutivamente por alguns subtipos de macrófagos e sua expressão pode aumentar em resposta a intérferons do tipo I (revisado em IZQUIERDO-USEROS et al., 2014).

Apesar da baixa expressão de Siglec-1 nas iDCs, essas células ainda são capazes de internalizar virions e trans-infectar linfócitos, indicando que outros receptores também podem mediar a internalização de HIV na ausência do Siglec-1 (IZQUIERDO-USEROS et al, 2012b). Entretanto, já foi demonstrado que as DCs maduras apresentam maior capacidade de trans-infecção que as DCs imaturas, provavelmente pelo aumento de expressão de Siglec-1 após a ativação (IZQUIERDO-USEROS et al., 2012b; PURYEAR et al., 2013).

Os mecanismos de internalização e transmissão do HIV-1 e o compartimento onde o vírus reside no interior das DCs ainda não estão totalmente elucidados. As evidências indicam que o HIV-1 fica em compartimentos ligados à membrana externa, ricos em tetraspaninas CD81 e CD9, e outras proteínas abundantes na membrana de DCs como HLA e CD86, mas que não apresentam marcadores lisossomais (LAMP-1 e CD63 - YU et al., 2008). Adicionalmente, esses compartimentos não são ácidos, indicando que não fazem parte do sistema endolisossomal (GARCIA et al., 2005).

A formação dos compartimentos nas DC depende apenas dos gangliosídeos na partícula viral, visto que vesículas unilamelares grandes e partículas de ouro recobertas por membranas lipídicas, ambos contendo GM3, são suficientes para a formação dos compartimentos (IZQUIERDO-USEROS et al., 2012; YU et al., 2015).

Os compartimentos virais se apresentam de forma diferente em iDCs e mDCs. Em iDCs são observados pequenos compartimentos periféricos, enquanto em na maioria das mDCs o vírus começa a ser internalizado em pontos diferentes da célula, mas após poucos minutos há uma convergência das partículas para um único compartimento. In vitro, estima-se que os vírions possam permanecer nos compartimentos por volta de quatro dias, mas sofrendo uma degradação gradativa durante esse período (YU et al., 2008).

Outra característica importante dos compartimentos em mDCs é que a sinapse com linfócitos sempre ocorre próxima aos compartimentos, seja porque o 
linfócito durante o scan em DCs se fixa próximo ao compartimento, ou porque o compartimento é transportado para a região de interação com o linfócitos (Yu et al., 2015). Essa preferência pode ser devida à alta concentração de CD81 que se associa a complexos de integrinas na membrana (CHENG et al., 2007; SERRU et al.,1999), no entanto não se sabe se estes complexos estão presentes nos compartimentos, ou se há acúmulo do CD81 sozinho.

Ainda nos anos 90, percebeu-se que o vírus proveniente de DCs infectava os linfócitos $\mathrm{T}$ durante a sinapse imunológica. Isso pôde ser concluído pois DCs depletadas das moléculas CD40 e CD80 (necessárias para coestimulação de linfócitos durante a sinapse imunológica) não realizam trans-infecção de linfócitos $T$ CD4 em repouso (PINCHUK et al., 1994). No entanto, as interações entre moléculas de adesão ICAM-1 (Intercellular Adhesion Molecule 1) e LFA-1 (Lymphocyte function-associated antigen 1) parecem ser mais importantes no processo quando a célula T já está ativada (WANG et al., 2006; RODRIGUEZ-PLATA et al, 2013).

Apesar da dificuldade em se estudar a trans-infecção por HIV-1 in vivo em humanos, alguns estudos indicam que as DCs podem ser importantes na patogenia do HIV-1. Alguns trabalhos observaram um aumento da expressão de Siglec-1 nas células mononucleares do sangue periférico (PMBC) de pacientes soropositivos na fase inicial da infecção por HIV. Além disso, os níveis de Siglec-1 diminuem em pacientes que respondem positivamente ao tratamento antirretroviral (KUYL et al., 2007; PINO et al., 2015). Isso é esperado, dado que sua expressão é regulada por intérferons tipo I (YORK et al., 2007), que estão aumentados durante a infecção por HIV-1 e tem níveis mais baixos durante o tratamento antirretroviral (BRAZILLE et al, 2003).

Recentemente, foi relatado que a transferência do MLV (murine leukemia vírus), um retrovírus murino usado como modelo para o HIV, do local de infecção até os linfonodos, é feita de forma dependente do receptor Siglec-1. O trabalho também relata que, sem esse receptor, a infecção não é capaz de se estabelecer (SEWALD et al., 2015). Além disso, um estudo correlaciona a baixa disseminação do HIV-2 in vivo a sua baixa capacidade de internalização por CD169 em DCs, que leva a uma menor taxa de trans-infecção (KIJEWSKI et al., 2016). 
Em contrapartida, Martinez-Picado (2016) e colaboradores analisaram, em uma coorte de pacientes HIV+, a incidência de indivíduos com uma mutação que levava à expressão de Siglec-1 não funcional (null). Verificou-se que a prevalência de indivíduos Siglec-1-null entre indivíduos HIV-1+ é a mesma da população não infectada, indicando que a mutação não protege os indivíduos da infecção, como acontece, por exemplo, com a mutação $\Delta 32$ no gene do receptor CCR5 (SAMSON et al., 1996). Apesar disso, a mutação é muito rara e seria necessário um coorte muito maior para obtenção de resultados mais conclusivos.

\subsection{Citoesqueleto e HIV}

O HIV-1 depende de diversas maquinarias da célula hospedeira para o sucesso de sua infecção, o que inclui o citoesqueleto, que participa de e é modulado em todas as etapas do ciclo de infecção do HIV (LEHMAN; NIKOLIC; PIGUET, 2011).

O citoesqueleto é constituído por três estruturas principais: microfilamentos, filamentos intermediários e microtúbulos. Em resumo, os microfilamentos ou filamentos de actina (Actina-F) são formados a partir da nucleação de monômeros de actina (actina-G ou globular) e estão envolvidos na motilidade da célula, endocitose, exocitose, contratilidade, entre outros. Os filamentos intermediários podem ser formados por uma grande variedade de proteínas que conferem resistência mecânica às células. Por fim, os microtúbulos, formados por $\alpha$ e $\beta$ tubulina, estão envolvidos no transporte intracelular de organelas e proteínas, divisão e locomoção celular (LEE et al., 2014; DHARAN; CAMPBELL, 2018).

Toda a montagem e regulação do citoesqueleto de actina é feita por diversas proteínas acessórias que auxiliam na montagem e desmontagem das estruturas, em especial as GTPases da família RHO, RhoA, Rac e Cdc42. As GTPases não interagem diretamente com a actina, mas quando ativadas, se ligam a proteínas efetoras que medeiam a nucleação ou desmontagem dos filamentos de actina (LEE et al., 2014).

O agrupamento dos receptores do HIV-1 (CD4, CXCR4 e CXCR5) é necessário para a entrada do vírus e subsequente infecção (YYENGAR et al., 1998). Tal processo depende da estabilização das redes de actina cortical, induzidas pela 
ligação de Env a CD4 e CXCR4 ou CCR5. Esta estabilização ativa vias de sinalização que culminam com a ativação de fatores de troca de nucleotídeo guanina (GEFs, guanine nucleotide exchange factor). Os GEFs promovem a nucleação da actina cortical por meio de Rac1 e Cdc42, que ativam o complexo arp2/3. A ligação da proteína Env a CD4 e CXCR4 também ativa RhoA que, juntamente com arp2/3, promove também a inibição da cofilina, permitindo a polimerização de actina e agrupamento dos receptores (STOLP; FLAKER, 2011; STELLA; TURVILLE, 2018)

No entanto, as redes de actina cortical constituem uma barreira após a fusão do vírion. A ligação do HIV-1 a um de seus correceptores também leva a uma posterior desfosforilação e consequente reativação da cofilina, que desestabiliza as redes de actina cortical, promovendo a movimentação do capsídeo para o interior da célula (YODER et al., 2008; PADILLA-PARRA e DUSTIN, 2016).

O HIV-1 utiliza os microtúbulos e as redes de actina para sua locomoção dentro da célula. A infecção por HIV-1 aumenta a disponibilidade de microtúbulos estáveis no citoplasma (destirosinados e acetilados - SABO et al., 2013) e estes medeiam o transporte do PIC e do capsídeo do citoplasma até os poros nucleares (MCDONALD et al., 2002).

O papel de proteínas dos microfilamentos nas etapas finais do ciclo do HIV (montagem e brotamento) ainda é discutido, visto que, apesar da interação física da gag com a actina e da incorporação de actina às partículas virais (WILK, GOHEN, FULLER, 1999), a perturbação do citoesqueleto de actina não interfere na liberação do vírus no sobrenadante na maioria das linhagens celulares (LEHMANN NIKOLIC; PIGUET, 2011).

Além do sequestro do citoesqueleto na infecção do HIV-1, algumas proteínas virais podem causar outras alterações. A proteína Nef, quando em associação com PAK2 (um alvo das enzimas Rac1 e CDC42) promove a fosforilação da cofilina (STOLP et al., 2009). Em células Jurkat, a Nef causa aumento no número de filopódios e diminui as pregas (ruffles) da membrana, prejudicando a migração celular (NOBILE et al., 2010).

O citoesqueleto também é essencial para a transferência célula-célula. As redes de actina medeiam a aglomeração e estabilidade dos receptores necessários 
para sinapse entre as duas células enquanto os microtúbulos polarizam para mediar o transporte das proteínas virais para a sinapse (LEHMANN; NIKOLIC; PIGUET, 2011).

Durante a infeção por HIV-1 em macrófagos, são observados compartimentos contendo vírus (VCCs). Tais compartimentos são locais de montagem e acúmulo de vírus. Possuem ligação com a membrana celular, são rodeados por actina polimerizada e possuem marcadores como as tetraspaninas CD81 e CD9, o receptor scavenger CD36, e integrinas (DANEKA et al., 2007; MLCOCHOVA et al., 2013; BERRE et al., 2013). Também nas DCs, os compartimentos formados durante a trans-infecção são sustentados e dependem de redes de actina-f (MCDONALD et al, 2003; YU et al., 2008; YU et al., 2015).

Proteínas motoras, associadas ou não com microtúbulos e microfilamentos, também são subvertidas pelo HIV. No estágio inicial da infecção, o transporte do capsídeo viral até o núcleo da célula do hospedeiro é mediado por dineínas (MCDONALD et al., 2002). As dineínas são proteínas motoras que se associam aos microtúbulos e promovem o transporte retrógrado de vesículas e proteínas (em direção ao MTOC e a extremidade negativa dos microtúbulos - HOOK; VALEE, 2006). Além do transporte, as dineínas também são necessárias para a desmontagem do capsídeo viral (PAWLICA; BERTHOUX et al., 2014).

As cinesinas também são proteínas motoras que se associam a microtúbulos, mas promovem o transporte anterógrado (em direção à extremidade positiva). $\mathrm{O}$ transporte mediado por cinesinas é importante principalmente na liberação de partículas virais de macrófagos infectados (GAUDIN et al., 2012). Cinesinas e a proteína adaptadora de cinesinas FEZ1 (Fasciculation And Elongation Protein Zeta 1) também seriam necessários para a orientação do transporte do capsídeo até o núcleo no inicio da infecção e na desmontagem do capsídeo (MALIKOV et al., 2015., 2017).

Apesar do papel de cinesinas e dineínas ter sido melhor estudado, as miosinas, proteínas motoras associadas principalmente às redes de actina, foram pouco estudadas e seu papel tanto na infecção por HIV-1 quanto na trans-infecção ainda não foi elucidado. Apesar do envolvimento das redes de actina em diversas fases do ciclo do HIV-1 e da trans-infecção, apenas a miosina 2 foi estudada no 
contexto da infecção e da trans-infecção (KADIU et al., 2011; MÉNAGER e LITTMAN, 2016).

Recentemente, algumas proteínas relacionadas à rede de actina foram associadas à internalização do vírus e desenvolvimento dos compartimentos. Entre elas, a miosina 2, cuja inibição resultou na redução da internalização do HIV-1 e no acúmulo de virions na membrana. O estudo também avaliou outras duas miosinas, a miosina $5 \mathrm{a}$ e a miosina $1 \mathrm{f}$. O silenciamento da miosina $5 \mathrm{a}$ levou à maior taxa de trans-infecção, porém, os autores não investigaram o papel da miosina no processo. O silenciamento da miosina $1 f$ não alterou a trans-infecção (MÉNAGER; LITTMAN, 2016).

Outro estudo acompanhou a movimentação de nanopartículas de ouro cobertas por GM3 e constatou que o padrão de movimentação dessas partículas após a internalização por DCs era compatível com a movimentação promovida por miosinas (YU et al., 2015).

\subsection{Miosinas}

O termo miosina foi cunhado por Kuhne em 1864, que extraiu de tecidos musculares uma proteína viscosa (revisto por Szent-Györgyi, 2004). Desde então, trinta e cinco famílias de miosinas foram identificadas, treze delas representadas por 40 genes, são expressas em células humanas (KNEUSSEL \& WAGNER, 2013). Análises de microarray demonstraram que 11 genes de miosinas (MYO1C, MYO1E, MY01F, MY01G, MYH9, MYO5A, MY07A, MYO9A, MYO9B, MY010 е MYO18A), distribuídas em sete famílias, eram expressos em DCs murinas (Figura 2 MARAVILLAS-MONTERO e SANTOS-ARGUMEDO, 2012).

As miosinas são compostas por uma ou duas cadeias pesadas específicas e cadeias leves associadas. As cadeias pesadas apresentam três domínios: cabeça, pescoço e cauda. A cabeça é globular e é responsável pela ligação aos filamentos de actina e pela hidrólise do ATP (adenosina trifosfato). A hidrólise do ATP gera a energia necessária para o movimento da miosina ao longo dos filamentos de actina. O pescoço contém motivos IQ (pequenos motivos com cerca de 20 aminoácidos que servem de ancora para ligação das cadeias leves). As cadeias leves são da família das calmodulinas e mantêm as ligações de actina-miosina estáveis devido a sua 
estrutura ser repleta de domínios de ligação a cálcio. O domínio caudal das miosinas é a porção mais variável entre as miosinas, e possui diversos motivos para interação com outras proteínas, e até mesmo ácidos nucleicos (revisado em LODISH, 2000).

A localização subcelular das miosinas é variada: a maior parte delas é citoplasmática; no entanto, algumas possuem domínios de ligação à membrana, como o caso da miosina 1c (myo1c) e da miosina 10. Alguma possuem sequências para importação nuclear, como o caso da myo1c. Suas funções também são diversas, apesar de a maioria delas estar envolvida no transporte de moléculas, como é o caso das miosinas 1c, 1e e 5a. As miosinas também estão envolvidas em processos de adesão e migração, sinalização, contratilidade e regulação da tensão de membrana (MARAVILLAS-MONTERO; SANTOS-ARGUMEDO, 2012).

O gene MYH9 codifica a cadeia pesada de uma miosina 2, que forma um homodímero. A miosina 2 foi uma das poucas estudadas no contexto do HIV-1. Durante a infecção por HIV-1, há uma regulação negativa da expressão do gene MYH9 e isso pode estar associado à nefropatia relacionada ao HIV (HAYS et al., 2014). Além disso, como citado anteriormente, o silenciamento ou inibição da miosina 2 resulta na diminuição da endocitose viral, mantendo os vírions do HIV-1 ligados à membrana da célula e proporcionando aumento na trans-infecção (MÉNAGER e LITTMAN et al., 2016).

\subsection{Miosinas tipo I}

As miosinas do tipo I possuem cadeias pesadas monoméricas e podem ter somente o domínio TH1, sendo então chamadas miosinas de cauda curta (myo1e e 1f); ou ter três domínios (TH1, TH2 e TH3), sendo então chamadas miosinas de cauda longa (myo1c e 1g). A figura 3 ilustra a estrutura das miosinas tipo $\mathrm{I}$. $\mathrm{O}$ domínio TH1 é necessário para a localização subcelular e ligação à membrana em miosinas do tipo I (DOBERSTEIN e POLLARD, 1992 ;MAZERIK et al., 2014). O domínio TH2 possui motivos de ligação à actina (JUNG et al., 1994). Já o domínio TH3 é, na verdade, um domínio SH3, que pode interagir com proteínas adaptadoras e cinases (KUROCHKINA e GUHA, 2013). 
Myosin $1 \mathrm{c} \& 1 \mathrm{~g}$

(short tail)

Myosin $1 \mathrm{e} \&$ if

(long tail)
Motor $\quad|||| \mid$ TH1

Motor
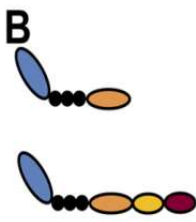

Figura 3. Miosinas tipo I. Quatro miosinas do tipo I são preditas de expressão em DCs e macrófagos. Miosinas de cauda curta (1c e 1g) possuem apenas o domínio TH1, enquanto as miosinas de cauda longa (1e e 1f) possuem três domínios, TH1, TH2 e SH3. Adaptado de MARAVILLAS-MONTERO; SANTOS-ARGUMEDO, 2011

Essas proteínas estão envolvidas em muitos processos celulares, incluindo transporte intracelular, endocitose, formação de lamelipodia e filopodia, controle da tensão da membrana e regulação do citoesqueleto (MARAVILLAS-MONTERO et al, 2011; MARAVILLAS-MONTERO; SANTOS-ARGUMEDO, 2012; MARAVILLASMONTERO et al, 2014). Em razão da homologia de sua estrutura, miosinas de cauda curta e de cauda longa parecem desempenhar funções redundantes. As miosinas 1c e 1g, por exemplo, estão envolvidas na migração celular e adesão de linfócitos B (MARAVILLAS-MONTERO; SANTOS-ARGUMEDO, 2011; 2014), enquanto as miosinas 1e e $1 \mathrm{f}$ participam da endocitose e expressão de HLA na membrana celular (WENZEL et al., 2015). Em decorrência disso, este trabalho está focado em uma miosina de cauda curta, a myo1c, e uma miosina de cauda longa, a miosina 1e (myo1e).

Foram descritas três isoformas da myo1c, sendo uma teoricamente nuclear e duas citoplasmáticas. A isoforma nuclear é necessária para a transcrição por causa de sua associação a complexos de remodelamento de cromatina e transcrição do DNA (SARSHAD et al., 2013). Ela é importada ao núcleo por meio de um motivo com 13 aminoácidos localizados no segundo domínio IQ, que é comum às três isoformas. Em razão disso, ainda se discute se as outras duas isoformas também poderiam ser importadas para o núcleo (DZIJAK et al., 2012).

As duas isoformas citoplasmáticas possuem um domínio na cauda que medeia sua aderência à membrana citoplasmática por meio de $\mathrm{PI}(4,5) \mathrm{P}_{2}$ (fosfatidilinositol bifosfato), um fosfolipídio presente na membrana especialmente em lipid rafts (HOKANSON et al., 2006; DZIJAK et al., 2012). 
Os lipid rafts são domínios de membrana ricos em colesterol e glicoesfingolipídios. Representam cerca de $50 \%$ da membrana plasmática, e são importantes para a concentração de moléculas de sinalização celular, tanto receptores de membrana, quanto cinases e alguns outros reguladores do citoesqueleto de actina como Rac e Cdc42 (PIKE et al., 2003). É interessante ressaltar que a montagem das partículas do HIV-1 ocorre quase sempre em lipid rafts ou em domínios ricos em tetraspaninas, que são locais com alta expressão de GM3, necessário para internalização do vírus por Siglec-1 em DCs (AKYIAMA et al., 2014).

Lipid rafts são constantemente endocitados em compartimentos perinucleares. Em associação com RalA (GTPase que se associa ao pescoço da myo1c), a myo1c promove a reciclagem desses compartimentos por meio do transporte até a membrana citoplasmática. Na ausência de myo1c, compartimentos com marcadores de lipid rafts se acumulam no espaço perinuclear e sua expressão diminui na membrana, enquanto que em caso de superexpressão de myo1c se observa aumento na quantidade de lipid rafts. O auxílio da myo1c no processo de reciclagem dessas moléculas acontece provavelmente por meio da estabilização de redes tubulares da membrana, às quais a miosina está associada (BRANDSTETTER et al., 2014).

Outro estudo demonstrou que, na ausência de myo1c, há acumulo de colesterol em membranas intracelulares. Essa alteração da composição das membranas intracelulares leva à deficiência na fusão de autofagossomos a lisossomos. Apesar disso, a ausência da miosina não altera a fusão de vesículas endocíticas e lisossomo, mas há uma clara mudança na morfologia destas organelas (BRANDSTETTER et al., 2014). Além disso, o trabalho só avaliou a endocitose de EGFR que ocorre pela via endocítica clássica mediada por clatrina, não avaliando outros tipos de endocitose, como a endocitose mediada por caveolina e outras vias não clássicas (MAYOR; PAGANO, 2007).

Também há ligação da myo1c à exocitose do transportador de glicose 4 (GLUT4). Após a ligação da insulina ao seu receptor, a myo1c é fosforilada por CaMKII, e se liga às vesículas com GLUT4 (ligação dependente de RalA), mediando 
o transporte até a membrana e a fusão da vesícula para expressão de GLUT4 (BOSE et al., 2002; YIP et al., 2008).

A myo1c também pode se ligar diretamente a proteínas e mediar seu transporte e fusão na membrana, como é o caso da neph1 e nephrin, que modulam o citoesqueleto para a formação das extensões de membrana presentes em células do rim (ARIF et al.,2011).

Em linfócitos B, a myo1c, aparece nas protrusões da membrana e nos lipid rafts e se acumula na sinapse imunológica com uma célula T. A myo1c pode se associar a moléculas de MHC classe II e sua ausência perturba a apresentação antigênica (MARAVILLAS-MONTERO et al., 2011).

A myo1e também está envolvida na apresentação antigênica. DCs e macrófagos de camundongos MYO1E -/- apresentam deficiência no tráfego de moléculas de MHC classe II para a membrana citoplasmática e consequentemente menor taxa de apresentação antigênica (WENZEL et al., 2015). Em DCs humanas, a Myo1e é recrutada por ARL14/ARF7 via ARF7EP para vesículas contendo MHC II (Paul et al., 2011).

Um estudo também relacionou a myo1e à exocitose de grânulos em oócitos de Xenopus. A miosina se associa aos grânulos corticais durante a fase inicial do desenvolvimento e promove a exocitose destes grânulos (SCHIETROMA.et al., 2007).

A myo1e é expressa no citoplasma em associação a SH3P2. Quando fosforilada, a SH3P2 se dissocia da myo1e e a libera para que migre para o lamelipódio (TANIMURA et al., 2016). No lamelipódio, a myo1e migra para os domínios de adesão nascentes, e o silenciamento ou inibição da myo1e leva a defeitos na elongação e estabilidade de adesões estáveis, que são eventos necessários para a migração celular (GUPTA et al., 2013).

É interessante ressaltar que a myo1e interage com a dinamina 2 (KENDREL et al., 2007), que é responsável pela macropinocitose de vírions de HIV-1 nos macrófagos (CARTER et al., 2011) e pode regular a internalização do HIV-1 em DCs (MÉNAGER e LITTMAN, 2016). Em células HeLa, a dinamina 2 recruta a myo1e para os locais de endocitose por meio do domínio SH3, e a expressão da cauda da 
miosina (que age como dominante negativo) reduz a endocitose de transferrina. No entanto, ainda não está claro qual o papel da myo1e na endocitose (KENDREL et al., 2007).

Fica claro que há grandes chances de que as miosinas influenciem na interação do HIV-1 com MDDCs. Contudo, as miosinas foram, de certa forma, negligenciadas nos estudos envolvendo o HIV-1. Sendo assim, neste trabalho nós avaliamos o envolvimento de duas miosinas do tipo I na interação de HIV-1 com MDDCs. 


\section{CONCLUSÕES}

- Ao menos 10 miosinas são expressas em MDDCs e a expressão dos genes da miosina 9b e 18a são regulados negativamente após a ativação com LPS;

- MDDCs de pacientes HIV+ apresentam menor expressão de MYO1C;

- A ausência da myo1c interferiu na ativação das MDDCs em resposta a LPS;

- A ausência da myo1c não interferiu na quantidade de HIV internalizado por MDDCs;

- A inibição da ativação de MDDCs provocada pela ausência da myo1c influenciou na internalização do HIV-1, de modo que quando avaliamos a localização dos vírions em MDDC maduras, os mesmos apresentaram fenótipo de internalização parecido com o que seria observado em MDDCs imaturas;

- A ausência da myo1e não influenciou na ativação de MDDCs ou na internalização do HIV-1. 


\section{REFERÊNCIAS BIBLIOGRÁFICAS}

AHMED, Zahra et al. The role of human dendritic cells in HIV-1 infection. Journal of Investigative Dermatology, v. 135, n. 5, p. 1225-1233, 2015.

AKIYAMA, Hisashi et al. Virus Particle Release From GSL-Enriched Microdomains Is Essential for Dendritic Cell-Mediated Capture and Transfer of HIV-1 and Henipavirus. Journal of virology, p. JVI. 00992-14, 2014.

ALTFELD, Marcus; GALE JR, Michael. Innate immunity against HIV-1 infection. Nature immunology, v. 16, n. 6, p. 554-562, 2015.

ARIF, E. et al. Motor protein Myo1c is a podocyte protein that facilitates the transport of slit diaphragm protein Neph1 to podocyte membrane. Molecular and cellular biology. 2011

BANCHEREAU, Jacques; STEINMAN, Ralph M. Dendritic cells and the control of immunity. Nature, v. 392, n. 6673, p. 245, 1998.

BARCHET, Winfried; CELLA, Marina; COLONNA, Marco. Plasmacytoid dendritic cells—virus experts of innate immunity. In: Seminars in immunology. Academic Press, 2005. p. 253-261.

BARRÉ-SINOUSSI, Françoise; ROSS, Anna Laura; DELFRAISSY, Jean-François. Past, present and future: 30 years of HIV research. Nature Reviews Microbiology, v. 11, n. 12, p. $877,2013$.

BEIGNON, Anne-Sophie et al. Endocytosis of HIV-1 activates plasmacytoid dendritic cells via Toll-like receptor-viral RNA interactions. The Journal of clinical investigation, v. 115, n. 11, p. 3265-3275, 2005.

BERRE, Stefano et al. CD36-specific antibodies block release of HIV-1 from infected primary macrophages and its transmission to T cells. Journal of Experimental Medicine, v. 210, n. 12, p. 2523-2538, 2013.

BLOCH, Nicolin et al. HIV type 1 infection of plasmacytoid and myeloid dendritic cells is restricted by high levels of SAMHD1 and cannot be counteracted by Vpx. AIDS research and human retroviruses, v. 30, n. 2, p. 195-203, 2014.

BOGGIANO, Cesar; MANEL, Nicolas; LITTMAN, Dan R. Dendritic cell-mediated transenhancement of human immunodeficiency virus type 1 infectivity is independent of DCSIGN. Journal of virology, v. 81, n. 5, p. 2519-2523, 2007.

BOND, Lisa M. et al. Functional roles for myosin $1 \mathrm{c}$ in cellular signaling pathways. Cellular signalling, v. 25, n. 1, p. 229-235, 2013.

BONGERTZ, Vera. Vertical human immunodeficiency virus type 1-HIV-1-transmission-a review. Memórias do Instituto Oswaldo Cruz, v. 96, n. 1, p. 1-14, 2001.

BOSE, Avirup et al. Glucose transporter recycling in response to insulin is facilitated by myosin Myo1c. Nature, v. 420, n. 6917, p. 821, 2002.

BOYETTE, Lisa B. et al. Phenotype, function, and differentiation potential of human monocyte subsets. PloS one, v. 12, n. 4, p. e0176460, $2017 .$.

BRANDSTAETTER, Hemma et al. Loss of functional MYO1C/myosin 1c, a motor protein involved in lipid raft trafficking, disrupts autophagosome-lysosome fusion. Autophagy, v. 10, n. 12, p. 2310-2323, 2014.

BRAZILLE, $P$. et al. Decreases in plasma TNF- $\alpha$ level and IFN- $\gamma$ mRNA level in peripheral blood mononuclear cells (PBMC) and an increase in IL-2 mRNA level in PBMC are 
associated with effective highly active antiretroviral therapy in HIV-infected patients. Clinical \& Experimental Immunology, v. 131, n. 2, p. 304-311, 2003.

BRETON, Gaëlle et al. Human dendritic cells (DCs) are derived from distinct circulating precursors that are precommitted to become CD1c+ or CD141+ DCs. Journal of Experimental Medicine, v. 213, n. 13, p. 2861-2870, 2016.

BRIONES, Marisa S.; DOBARD, Charles W.; CHOW, Samson A. Role of human immunodeficiency virus type 1 integrase in uncoating of the viral core. Journal of virology, v. 84, n. 10, p. 5181-5190, 2010.

CAMERON, P. U. et al. During HIV-1 infection most blood dendritic cells are not productively infected and can induce allogeneic CD4+ T cells clonal expansion. Clinical \& Experimental Immunology, v. 88, n. 2, p. 226-236, 1992a.

CAMPBELL, Edward M.; HOPE, Thomas J. HIV-1 capsid: the multifaceted key player in HIV1 infection. Nature reviews. Microbiology, v. 13, n. 8, p. 471, 2015.

CARTER, Gemma C. et al. HIV-1 infects macrophages by exploiting an endocytic route dependent on dynamin, Rac1 and Pak1. Virology, v. 409, n. 2, p. 234-250, 2011.

CHANG, Yongen; FINNEMANN, Silvia C. Tetraspanin CD81 is required for the av $\beta 5$-integrindependent particle-binding step of RPE phagocytosis. Journal of cell science, v. 120, n. 17, p. 3053-3063, 2007.

CHAPUIS, Françoise et al. Differentiation of human dendritic cells from monocytes in vitro. European journal of immunology, v. 27, n. 2, p. 431-441, 1997.

CHENG, Jackie; GRASSART, Alexandre; DRUBIN, David G. Myosin 1E coordinates actin assembly and cargo trafficking during clathrin-mediated endocytosis. Molecular biology of the cell, v. 23, n. 15, p. 2891-2904, 2012.

CHINTHALAPUDI, Krishna et al. Mechanism and specificity of pentachloropseudilinmediated inhibition of myosin motor activity. Journal of Biological Chemistry, v. 286, n. 34, p. 29700-29708, 2011.

CLARK, Evan; NAVA, Brenda; CAPUTI, Massimo. Tat is a multifunctional viral protein that modulates cellular gene expression and functions. Oncotarget, v. 8, n. 16, p. 27569, 2017.

DEEKS, Steven G. et al. HIV infection. Nature reviews. Disease primers, v. 1, p. 1503515035, 2015.

DENEKA, Magdalena et al. In macrophages, HIV-1 assembles into an intracellular plasma membrane domain containing the tetraspanins CD81, CD9, and CD53. The Journal of cell biology, v. 177, n. 2, p. 329-341, 2007.

DING, Lingmei et al. Independent segregation of human immunodeficiency virus type $1 \mathrm{Gag}$ protein complexes and lipid rafts. Journal of virology, v. 77, n. 3, p. 1916-1926, 2003.

DOBERSTEIN, Stephen K.; POLLARD, Thomas D. Localization and specificity of the phospholipid and actin binding sites on the tail of Acanthamoeba myosin IC. The Journal of Cell Biology, v. 117, n. 6, p. 1241-1249, 1992.

DZIJAK, Rastislav et al. Specific nuclear localizing sequence directs two myosin isoforms to the cell nucleus in calmodulin-sensitive manner. PloS one, v. 7, n. 1, p. e30529, 2012.

F ARIAS, Juan; IWABU, Yukie; TOKUNAGA, Kenzo. Sites of action of HIV-1 Vpu in BST2/tetherin downregulation. Current HIV research, v. 10, n. 4, p. 283-291, 2012.

facilitates innate immune signaling. Cytokine, v. 48, n. 1, p. 128, 2009. 
FEINBERG, Mark B.; BALTIMORE, David; FRANKEL, Alan D. The role of Tat in the human immunodeficiency virus life cycle indicates a primary effect on transcriptional elongation. Proceedings of the National Academy of Sciences, v. 88, n. 9, p. 4045-4049, 1991.vitro. European journal of immunology, v. 27, n. 2, p. 431-441, 1997.

FISCHER, Utz et al. The HIV-1 Rev activation domain is a nuclear export signal that accesses an export pathway used by specific cellular RNAs. Cell, v. 82, n. 3, p. 475-483, 1995.

FITZGERALD, Katherine A. The interferon inducible gene: Viperin. Journal of Interferon \& Cytokine Research, v. 31, n. 1, p. 131-135, 2011.

GAO, Daxing et al. Cyclic GMP-AMP synthase is an innate immune sensor of HIV and other retroviruses. Science, v. 341, n. 6148, p. 903-906, 2013.

GAO, Pu et al. Binding-pocket and lid-region substitutions render human STING sensitive to the species-specific drug DMXAA. Cell reports, v. 8, n. 6, p. 1668-1676, 2014.

GARCIA, Eduardo et al. HIV-1 Trafficking to the Dendritic Cell-T-Cell Infectious Synapse Uses a Pathway of Tetraspanin Sorting to the Immunological Synapse. Traffic, v. 6, n. 6, p. 488-501, 2005.

GARTNER, Suzanne et al. Virus isolation from and identification of HTLV-III/LAV-producing cells in brain tissue from a patient with AIDS. Jama, v. 256, n. 17, p. 2365-2371, 1986.

GAUDIN, Raphaël et al. Critical role for the kinesin KIF3A in the HIV life cycle in primary human macrophages. J Cell Biol, v. 199, n. 3, p. 467-479, 2012.

GAVRILOV, Kseniya et al. Enhancing potency of siRNA targeting fusion genes by optimization outside of target sequence. Proceedings of the National Academy of Sciences, v. 112, n. 48, p. E6597-E6605, 2015.

GEIJTENBEEK, Teunis BH et al. DC-SIGN, a dendritic cell-specific HIV-1-binding protein that enhances trans-infection of T cells. Cell, v. 100, n. 5, p. 587-597, 2000.

GIESELER, Robert et al. In-vitro differentiation of mature dendritic cells from human blood monocytes. Clinical and Developmental Immunology, v. 6, n. 1-2, p. 25-39, 1998.

GOFFINET, Christine et al. HIV-1 antagonism of CD317 is species specific and involves Vpu-mediated proteasomal degradation of the restriction factor. Cell host \& microbe, v. 5, n. 3, p. 285-297, 2009.

GOLDSTONE, David C. et al. HIV-1 restriction factor SAMHD1 is a deoxynucleoside triphosphate triphosphohydrolase. Nature, v. 480, n. 7377, p. 379, 2011.

GOUJON, Caroline et al. SIV SM/HIV-2 Vpx proteins promote retroviral escape from a proteasome-dependent restriction pathway present in human dendritic cells. Retrovirology, v. 4, n. 1, p. 2, 2007.

GRANELLI-PIPERNO, Angela et al. Efficient interaction of HIV-1 with purified dendritic cells via multiple chemokine coreceptors. Journal of Experimental Medicine, v. 184, n. 6, p. 2433-2438, 1996.

GUMMULURU, Suryaram et al. Binding of human immunodeficiency virus type 1 to immature dendritic cells can occur independently of DC-SIGN and mannose binding C-type lectin receptors via a cholesterol-dependent pathway. Journal of virology, v. $77, n$. $23, p$. 12865-12874, 2003.

Gupta, Prabuddha, et al. "Myosin 1E localizes to actin polymerization sites in lamellipodia, affecting actin dynamics and adhesion formation." Biology open (2013): BIO20135827. 
HANIFFA, Muzlifah et al. Human tissues contain CD141 hi cross-presenting dendritic cells with functional homology to mouse CD103+ nonlymphoid dendritic cells. Immunity, v. 37, n. 1, p. 60-73, 2012.

HANIFFA, Muzlifah; BIGLEY, Venetia; COLLIN, Matthew. Human mononuclear phagocyte system reunited. In: Seminars in cell \& developmental biology. Academic Press, 2015. p. 59-69.

HANIFFA, Muzlifah; COLLIN, Matthew; GINHOUX, Florent. Ontogeny and functional specialization of dendritic cells in human and mouse. In: Advances in immunology. Academic Press, 2013. p. 1-49.

HANSASUTA, Pokrath; ROWLAND-JONES, Sarah L. HIV-1 transmission and acute HIV-1 infection. British medical bulletin, v. 58, n. 1, p. 109-127, 2001.

HAYS, Thomas et al. Glomerular MYH9 expression is reduced by HIV-1. AIDS (London, England), v. 26, n. 7, p. 797, 2012.

HOKANSON, David E. et al. Myo1c binds phosphoinositides through a putative pleckstrin homology domain. Molecular biology of the cell, v. 17, n. 11, p. 4856-4865, 2006.

HONEYCUTT, Jenna B. et al. HIV persistence in tissue macrophages of humanized myeloidonly mice during antiretroviral therapy. Nature medicine, v. 23, n. 5, p. 638, 2017.

HONG, Feiyu F.; MELLORS, John W. Changes in HIV reservoirs during long-term antiretroviral therapy. Current Opinion in HIV and AIDS, v. 10, n. 1, p. 43, 2015.

HÖÖK, Peter; VALLEE, Richard B. The dynein family at a glance. Journal of cell science, v. 119, n. 21, p. 4369-4371, 2006.

HOPE, T. J.; TRONO, D. Structure, expression, and regulation of the HIV genome. HIV InSite Knowledge Base Chapter (http:// hivinsite. ucsf. edu/ InSite, 2000.

HU, Wei-Shau; HUGHES, Stephen H. HIV-1 reverse transcription. Cold Spring Harbor perspectives in medicine, v. 2, n. 10, p. a006882, 2012.

HÜBNER, Wolfgang et al. Sequence of human immunodeficiency virus type 1 (HIV-1) Gag localization and oligomerization monitored with live confocal imaging of a replicationcompetent, fluorescently tagged HIV-1. Journal of virology, v. 81, n. 22, p. 12596-12607, 2007.

HÜBNER, Wolfgang et al. Sequence of human immunodeficiency virus type 1 (HIV-1) Gag localization and oligomerization monitored with live confocal imaging of a replicationcompetent, fluorescently tagged HIV-1. Journal of virology, v. 81, n. 22, p. 12596-12607, 2007.

ISHIKAWA, Hiroki; BARBER, Glen N. Sting is an endoplasmic reticulum adaptor that facilitates innate immune signaling. Cytokine, v. 48, n. 1, p. 128, 2009.

IYENGAR, Sujatha; HILDRETH, James EK; SCHWARTZ, David H. Actin-dependent receptor colocalization required for human immunodeficiency virus entry into host cells. Journal of virology, v. 72, n. 6, p. 5251-5255, 1998.

IZQUIERDO-USEROS, Nuria et al. HIV-1 capture and transmission by dendritic cells: the role of viral glycolipids and the cellular receptor Siglec-1. PLoS pathogens, v. 10, n. 7, p. e1004146, 2014.

IZQUIERDO-USEROS, Nuria et al. Maturation of blood-derived dendritic cells enhances human immunodeficiency virus type 1 capture and transmission. Journal of virology, v. 81, n. 14, p. 7559-7570, 2007. 
IZQUIERDO-USEROS, Nuria et al. Sialyllactose in viral membrane gangliosides is a novel molecular recognition pattern for mature dendritic cell capture of HIV-1. PLoS biology, v. 10, n. 4, p. e1001315, 2012a.

IZQUIERDO-USEROS, Nuria et al. Siglec-1 is a novel dendritic cell receptor that mediates HIV-1 trans-infection through recognition of viral membrane gangliosides. PLoS biology, $v$. 10, n. 12, p. e1001448, 2012b.

JAKOBSEN, Martin R. et al. IFI16 senses DNA forms of the lentiviral replication cycle and controls HIV-1 replication. Proceedings of the National Academy of Sciences, v. 110, $\mathrm{n}$. 48, p. E4571-E4580, 2013.

JAYAPPA, Kallesh Danappa; AO, Zhujun; YAO, Xiaojian. The HIV-1 passage from cytoplasm to nucleus: the process involving a complex exchange between the components of HIV-1 and cellular machinery to access nucleus and successful integration. International journal of biochemistry and molecular biology, v. 3, n. 1, p. 70, 2012.

JIN, Tengchuan et al. Structures of the HIN domain: DNA complexes reveal ligand binding and activation mechanisms of the AIM2 inflammasome and IFI16 receptor. Immunity, v. 36, n. 4 , p.

JOINT UNITED NATIONS PROGRAMME ON HIVIAIDS et al. Global report: UNAIDS report on the global AIDS epidemic 2010. UNAIDS, 2010.

JONGBLOED, Sarah L. et al. Human CD141+ (BDCA-3)+ dendritic cells (DCs) represent a unique myeloid DC subset that cross-presents necrotic cell antigens. Journal of Experimental Medicine, v. 207, n. 6, p. 1247-1260, 2010

JUNG, Goeh; HAMMER, John A. The actin binding site in the tail domain of Dictyostelium myosin 1C (myoC) resides within the glycine-and proline-rich sequence (tail homology region 2). FEBS letters, v. 342, n. 2, p. 197-202, 1994.

KADIU, Irena; GENDELMAN, Howard E. Human immunodeficiency virus type 1 endocytic trafficking through macrophage bridging conduits facilitates spread of infection. Journal of neuroimmune pharmacology, v. 6, n. 4, p. 658, 2011.

KANDATHIL, Abraham Joseph; SUGAWARA, Sho; BALAGOPAL, Ashwin. Are T cells the only HIV-1 reservoir?. Retrovirology, v. 13, n. 1, p. 86, 2016.

KESSING, Cari F. et al. In vivo suppression of HIV rebound by didehydro-cortistatin $A$, a "Block-and-Lock" strategy for HIV-1 treatment. Cell reports, v. 21, n. 3, p. 600-611, 2017.

KIJEWSKI, Suzanne DG et al. Access of HIV-2 to CD169-dependent dendritic cell-mediated trans infection pathway is attenuated. Virology, v. 497, p. 328-336, 2016.

KIRSCHNER, Denise E. The Dual Role of Dendritic cells in the Immune Response to HIV-1 Infection. J Gen Virol, v. 89, n. Pt 9, p. 2228-2239, 2008.

KNEUSSEL, Matthias; WAGNER, Wolfgang. Myosin motors at neuronal synapses: drivers of membrane transport and actin dynamics. Nature Reviews Neuroscience, v. 14, n. 4, p. 233, 2013.

KRENDEL, Mira; OSTERWEIL, Emily K.; MOOSEKER, Mark S. Myosin 1E interacts with synaptojanin-1 and dynamin and is involved in endocytosis. FEBS letters, v. 581, n. 4, p. 644-650, 2007.

KUPZIG, Sabine et al. Bst-2/HM1. 24 is a raft-associated apical membrane protein with an unusual topology. Traffic, v. 4, n. 10, p. 694-709, 2003. 
KUROCHKINA, Natalya; GUHA, Udayan. SH3 domains: modules of protein-protein interactions. Biophysical reviews, v. 5, n. 1, p. 29-39, 2013.

KUYL, A.C et al. Sialoadhesin (CD169) Expression in CD14+ Cells Is Upregulated Early after HIV-1 Infection and Increases during Disease Progression. PLoS One, v. 2, n.2, p e257, 2007.

LAGUETTE, Nadine et al. SAMHD1 is the dendritic-and myeloid-cell-specific HIV-1 restriction factor counteracted by Vpx. Nature, v. 474, n. 7353, p. 654, 2011.

LAHOUASSA, Hichem et al. SAMHD1 restricts the replication of human immunodeficiency virus type 1 by depleting the intracellular pool of deoxynucleoside triphosphates. Nature immunology, v. 13, n. 3, p. 223-228, 2012.

LE BORGNE, Marie et al. Dendritic cells rapidly recruited into epithelial tissues via CCR6/CCL20 are responsible for CD8+ T cell crosspriming in vivo. Immunity, v. 24, n. 2, p. 191-201, 2006.

LEARMONT, Jennifer C. et al. Immunologic and virologic status after 14 to 18 years of infection with an attenuated strain of HIV-1-a report from the Sydney Blood Bank Cohort. New England Journal of Medicine, v. 340, n. 22, p. 1715-1722, 1999

LEHMANN, Martin; NIKOLIC, Damjan S.; PIGUET, Vincent. How HIV-1 takes advantage of the cytoskeleton during replication and cell-to-cell transmission. Viruses, v. 3, n. 9, p. 17571776, 2011.

LEÓN, Beatriz; LÓPEZ-BRAVO, María; ARDAVÍN, Carlos. Monocyte-derived dendritic cells formed at the infection site control the induction of protective $T$ helper 1 responses against Leishmania. Immunity, v. 26, n. 4, p. 519-531, 2007.

LEWIS, Paul; HENSEL, Michelle; EMERMAN, Michael. Human immunodeficiency virus infection of cells arrested in the cell cycle. The EMBO journal, v. 11, n. 8, p. 3053, 1992.

LIU, Yong-Jun. Dendritic cell subsets and lineages, and their functions in innate and adaptive immunity. Cell, v. 106, n. 3, p. 259-262, 2001.

LIU, Zhenlong et al. The interferon-inducible MxB protein inhibits HIV-1 infection. Cell host \& microbe, v. 14, n. 4, p. 398-410, 2013.

LODISH, Harvey et al. Myosin: The Actin Motor Protein. 2000.

LUBAN, Jeremy et al. Human immunodeficiency virus type 1 Gag protein binds to cyclophilins A and B. Cell, v. 73, n. 6, p. 1067-1078, 1993.

LUNDBERG, Kristina et al. Human blood dendritic cell subsets exhibit discriminative pattern recognition receptor profiles. Immunology, v. 142, n. 2, p. 279-288, 2014.

MAGÉRUS-CHATINET, Aude et al. Galactosyl ceramide expressed on dendritic cells can mediate HIV-1 transfer from monocyte derived dendritic cells to autologous T cells. Virology, v. 362, n. 1, p. 67-74, 2007.

MAKOWSKA, Katarzyna A. et al. Specific myosins control actin organization, cell morphology, and migration in prostate cancer cells. Cell reports, v. 13, n. 10, p. 2118-2125, 2015.

MALIKOV, Viacheslav; NAGHAVI, Mojgan H. Localized phosphorylation of a kinesin-1 adaptor by a capsid-associated kinase regulates HIV-1 motility and uncoating. Cell reports, v. 20, n. 12, p. 2792-2799, 2017.

MALIKOV, Viacheslav; NAGHAVI, Mojgan H. Localized phosphorylation of a kinesin-1 adaptor by a capsid-associated kinase regulates HIV-1 motility and uncoating. Cell reports, v. 20, n. 12, p. 2792-2799, 2017. 
MALIM, Michael H.; EMERMAN, Michael. HIV-1 accessory proteins-ensuring viral survival in a hostile environment. Cell host \& microbe, v. 3, n. 6, p. 388-398, 2008.

MANGINO, Giorgio et al. HIV-1 Nef induces proinflammatory state in macrophages through its acidic cluster domain: involvement of TNF alpha receptor associated factor 2. PLoS One, v. 6, n. 8, p. e22982, 2011.

MANN, D. L. et al. HIV-1 transmission and function of virus-infected monocytes/macrophages. The Journal of Immunology, v. 144, n. 6, p. 2152-2158, 1990.

MARAVILLAS-MONTERO, José L. et al. Myosin 1c participates in B cell cytoskeleton rearrangements, is recruited to the immunologic synapse, and contributes to antigen presentation. The Journal of Immunology, v. 187, n. 6, p. 3053-3063, 2011.

MARAVILLAS-MONTERO, José L. et al. Myosin $1 \mathrm{~g}$ regulates cytoskeleton plasticity, cell migration, exocytosis, and endocytosis in B lymphocytes. European journal of immunology, v. 44, n. 3, p. 877-886, 2014.

MARAVILLAS-MONTERO, José L.; SANTOS-ARGUMEDO, Leopoldo. The myosin family: unconventional roles of actin-dependent molecular motors in immune cells. Journal of leukocyte biology, v. 91, n. 1, p. 35-46, 2012.

MARTINEZ-PICADO, Javier et al. Identification of Siglec-1 null individuals infected with HIV1. Nature communications, v. 7, 2016.

MATREYEK, Kenneth A. et al. Host and viral determinants for MxB restriction of HIV-1 infection. Retrovirology, v. 11, n. 1, p. 90, 2014.

MAYOR, Satyajit; PAGANO, Richard E. Pathways of clathrin-independent endocytosis. Nature reviews Molecular cell biology, v. 8, n. 8, p. 603, 2007.

MAZERIK, Jessica N. et al. Motor and tail homology 1 (Th1) domains antagonistically control myosin-1 dynamics. Biophysical journal, v. 106, n. 3, p. 649-658, 2014.

MCDONALD, David et al. Recruitment of HIV and its receptors to dendritic cell-T cell junctions. Science, v. 300, n. 5623, p. 1295-1297, 2003.

MCDONALD, David et al. Visualization of the intracellular behavior of HIV in living cells. The Journal of cell biology, v. 159, n. 3, p. 441-452, 2002.

MCDONALD, David. Dendritic cells and HIV-1 trans-infection. Viruses, v. 2, n. 8, p. 17041717, 2010.

MÉNAGER, Mickaël M.; LITTMAN, Dan R. Actin dynamics regulates dendritic cell-mediated transfer of HIV-1 to T cells. Cell, v. 164, n. 4, p. 695-709, 2016.

MERAD, Miriam et al. The dendritic cell lineage: ontogeny and function of dendritic cells and their subsets in the steady state and the inflamed setting. Annual review of immunology, $v$. 31, p. 563-604, 2013.

MINISTÉRIO DA SAÚDE (BR). Boletim epidemiológico HIV-Aids. 201.

MLCOCHOVA, Petra; PELCHEN-MATTHEWS, Annegret; MARSH, Mark. Organization and regulation of intracellular plasma membrane-connected HIV-1 assembly compartments in macrophages. BMC biology, v. 11, n. 1, p. 89, 2013.

MORIS, Arnaud et al. Dendritic cells and HIV-specific CD4+ T cells: HIV antigen presentation, T-cell activation, and viral transfer. Blood, v. 108, n. 5, p. 1643-1651, 2006. 
NEGRE, D. et al. Characterization of novel safe lentiviral vectors derived from simian immunodeficiency virus (SIVmac251) that efficiently transduce mature human dendritic cells. Gene therapy, v. 7, n. 19, p. 1613, 2000.

NOBILE, Cinzia et al. HIV-1 Nef inhibits ruffles, induces filopodia, and modulates migration of infected lymphocytes. Journal of virology, v. 84, n. 5, p. 2282-2293, 2010.

O'BRIEN, Meagan; MANCHES, Olivier; BHARDWAJ, Nina. Plasmacytoid dendritic cells in HIV infection. In: HIV interactions with dendritic cells. Springer New York, 2012. p. 71-107.

OSPINA STELLA, Alberto; TURVILLE, Stuart. All-Round Manipulation of the Actin Cytoskeleton by HIV. Viruses, v. 10, n. 2, p. 63, 2018.

PADILLA-PARRA, Sergi; DUSTIN, Michael L. Actin dynamics and HIV-1 entry. Trends in molecular medicine, v. 22, n. 5, p. 354-356, 2016.

PAIARDINI, Mirko; MÜLLER-TRUTWIN, Michaela. HIV-associated chronic immune activation. Immunological reviews, v. 254, n. 1, p. 78-101, 2013.

PAUL, Petra et al. A Genome-wide multidimensional RNAi screen reveals pathways controlling MHC class II antigen presentation. Cell, v. 145, n. 2, p. 268-283, 2011.

PAWLICA, Paulina; BERTHOUX, Lionel. Cytoplasmic dynein promotes HIV-1 uncoating. Viruses, v. 6, n. 11, p. 4195-4211, 2014.

PELCHEN-MATTHEWS, Annegret et al. $\beta 2$ Integrin Adhesion Complexes Maintain the Integrity of HIV-1 Assembly Compartments in Primary Macrophages. Traffic, v. 13, n. 2, p. 273-291, 2012.

PIGUET, Vincent et al. The downregulation of CD4 and MHC-I by primate lentiviruses: A paradigm for the modulation of cell surface receptors. Immunological reviews, v. 168, n. 1, p. 51-63, 1999.

PIKE, Linda J. Lipid rafts bringing order to chaos. Journal of lipid research, v. 44, n. 4, p. 655-667, 2003.

PINCHUK, Lesya M. et al. The role of CD40 and CD80 accessory cell molecules in dendritic cell-dependent HIV-1 infection. Immunity, v. 1, n. 4, p. 317-325, 1994.

PINO, Maria et al. HIV-1 immune activation induces Siglec-1 expression and enhances viral trans-infection in blood and tissue myeloid cells, Retrovirology, v. 12, n. 37, 2015.

POPE, M. et al. Conjugates of dendritic cells and memory $T$ lymphocytes from skin facilitate productive infection with HIV-1. Cell, v. 78, n. 3, p. 389-398, 1994.

PURYEAR, Wendy Blay et al. HIV-1 incorporation of host-cell-derived glycosphingolipid GM3 allows for capture by mature dendritic cells. Proceedings of the National Academy of Sciences, v. 109, n. 19, p. 7475-7480, 2012.

PURYEAR, Wendy Blay et al. Interferon-inducible mechanism of dendritic cell-mediated HIV1 dissemination is dependent on Siglec-1/CD169. PLoS pathogens, v. 9, n. 4, p. e1003291, 2013.

PURYEAR, Wendy Blay; GUMMULURU, Suryaram. Role of glycosphingolipids in dendritic cell-mediated HIV-1 trans-infection. In: HIV Interactions with Dendritic Cells. Springer, New York, NY, 2012. p. 131-153.

RANDOLPH, Gwendalyn J. Dendritic cell migration to lymph nodes: cytokines, chemokines, and lipid mediators. In: Seminars in immunology. Academic Press, 2001. p. 267-274. 
RANDOLPH, Gwendalyn J. et al. Differentiation of phagocytic monocytes into lymph node dendritic cells in vivo. Immunity, v. 11, n. 6, p. 753-761, 1999.

RANDOLPH, Gwendalyn J. et al. The CD16+ (FcyRIII+) subset of human monocytes preferentially becomes migratory dendritic cells in a model tissue setting. Journal of Experimental Medicine, v. 196, n. 4, p. 517-527, 2002.

REIZIS, Boris et al. Plasmacytoid dendritic cells: recent progress and open questions. Annual review of immunology, v. 29, p. 163-183, 2011.

RIBEIRO, Carla MS et al. Receptor usage dictates HIV-1 restriction by human TRIM5 $\alpha$ in dendritic cell subsets. Nature, v. 540, n. 7633, p. 448, 2016.

RODRIGUEZ-PLATA, Maria T. et al. HIV-1 capture and antigen presentation by dendritic cells: enhanced viral capture does not correlate with better T cell activation. The Journal of Immunology, p. 1200267, 2012.

RODRIGUEZ-PLATA, Maria T. et al. The infectious synapse formed between mature dendritic cells and CD4+ T cells is independent of the presence of the HIV-1 envelope glycoprotein. Retrovirology, v. 10, n. 1, p. 42, 2013.

ROSA, Annachiara et al. HIV-1 Nef promotes infection by excluding SERINC5 from virion incorporation. Nature, v. 526, n. 7572, p. 212, 2015.

RUYSSCHAERT, Jean-Marie; LONEZ, Caroline. Role of lipid microdomains in TLRmediated signalling. Biochimica et Biophysica Acta (BBA)-Biomembranes, v. 1848, n. 9, p. 1860-1867, 2015.

SABO, Yosef et al. HIV-1 induces the formation of stable microtubules to enhance early infection. Cell host \& microbe, v. 14, n. 5, p. 535-546, 2013.

SALLUSTO, Federica; LANZAVECCHIA, Antonio. Efficient presentation of soluble antigen by cultured human dendritic cells is maintained by granulocyte/macrophage colony-stimulating factor plus interleukin 4 and downregulated by tumor necrosis factor alpha. Journal of Experimental Medicine, v. 179, n. 4, p. 1109-1118, 1994.

SALVERMOSER, Melanie et al. Myosin $1 \mathrm{f}$ is specifically required for neutrophil migration in 3D environments during acute inflammation. Blood, p. blood-2017-10-811851, 2018.

SAMSON, Michel et al. Resistance to HIV-1 infection in caucasian individuals bearing mutant alleles of the CCR-5 chemokine receptor gene. Nature, v. 382, n. 6593, p. 722, 1996.

SANDERS, Rogier W. et al. Differential transmission of human immunodeficiency virus type 1 by distinct subsets of effector dendritic cells. Journal of virology, v. $76, n$. 15, p. 78127821, 2002. 561-571, 2012.

SARSHAD, Aishe et al. Nuclear myosin 1c facilitates the chromatin modifications required to activate rRNA gene transcription and cell cycle progression. PLoS genetics, v. 9, n. 3, p. e1003397, 2013.

SASTRI, Jaya; CAMPBELL, Edward M. Recent insights into the mechanism and consequences of TRIM5a retroviral restriction. AIDS research and human retroviruses, $v$. 27, n. 3, p. 231-238, 2011.

SATO, Katsuaki; FUJITA, Shigeharu. Dendritic cells-nature and classification. Allergology International, v. 56, n. 3, p. 183-191, 2007.

SCHIETROMA, Cataldo et al. A role for myosin 1e in cortical granule exocytosis in Xenopus oocytes. Journal of Biological Chemistry, v. 282, n. 40, p. 29504-29513, 2007. 
SCHOGGINS, John W.; RICE, Charles M. Interferon-stimulated genes and their antiviral effector functions. Current opinion in virology, v. 1, n. 6, p. 519-525, 2011.

SERRU, V. et al. Cell biology and development-Selective tetraspan--Integrin complexes (CD81/a4b1, CD151/a3b1, CD151/a6b1) under conditions disrupting tetraspan interactions. Biochemical Journal, v. 340, n. 1, p. 103-112, 1999.

SEWALD, Xaver et al. Retroviruses use CD169-mediated trans-infection of permissive lymphocytes to establish infection. Science, v. 350, n. 6260, p. 563-567, 2015.

SHARP, Paul M.; HAHN, Beatrice $H$. The evolution of HIV-1 and the origin of AIDS. Philosophical Transactions of the Royal Society of London B: Biological Sciences, v. 365, n. 1552, p. 2487-2494, 2010.

SILVIN, Aymeric et al. Constitutive resistance to viral infection in human CD141+ dendritic cells. Science immunology, v. 2, n. 13, 2017.

SIMON, Viviana; BLOCH, Nicolin; LANDAU, Nathaniel R. Intrinsic host restrictions to HIV-1 and mechanisms of viral escape. Nature immunology, v. 16, n. 6, p. 546-553, 2015.

SIMONS, Kai; EHEHALT, Robert. Cholesterol, lipid rafts, and disease. The Journal of clinical investigation, v. 110, n. 5, p. 597-603, 2002.

SMED-SÖRENSEN, Anna et al. Differential susceptibility to human immunodeficiency virus type 1 infection of myeloid and plasmacytoid dendritic cells. Journal of virology, v. $79, \mathrm{n}$. 14, p. 8861-8869, 2005.

SOKAC, Anna M. et al. Myosin-1c couples assembling actin to membranes to drive compensatory endocytosis. Developmental cell, v. 11, n. 5, p. 629-640, 2006.

SOPER, Andrew et al. Type I Interferon Responses by HIV-1 Infection: Association with Disease Progression and Control. Frontiers in immunology, v. 8, p. 1823, 2018.

STOLP, Bettina; FACKLER, Oliver T. How HIV takes advantage of the cytoskeleton in entry and replication. Viruses, v. 3, n. 4, p. 293-311, 2011.

STREMLAU, Matthew et al. The cytoplasmic body component TRIM5 $\alpha$ restricts HIV-1 infection in Old World monkeys. Nature, v. 427, n. 6977, p. 848, 2004.

SUGAYA, Makoto et al. HIV-infected Langerhans cells preferentially transmit virus to proliferating autologous CD4+ memory $T$ cells located within Langerhans cell- $T$ cell clusters. The Journal of Immunology, v. 172, n. 4, p. 2219-2224, 2004.

SUNDQUIST, Wesley I.; KRÄUSSLICH, Hans-Georg. HIV-1 assembly, budding, and maturation. Cold Spring Harbor perspectives in medicine, v. 2, n. 7, p. a006924, 2012.

TANAKA, Yasuo; CHEN, Zhijian J. STING specifies IRF3 phosphorylation by TBK1 in the cytosolic DNA signaling pathway. Science signaling, v. 5, n. 214, p. ra20-ra20, 2012.

TANIMURA, Susumu et al. ERK signaling promotes cell motility by inducing the localization of myosin 1E to lamellipodial tips. J Cell Biol, p. jcb. 201503123, 2016.

TURVILLE, Stuart G. et al. Diversity of receptors binding HIV on dendritic cell subsets. Nature immunology, v. 3, n. 10, p. 975, 2002.

TURVILLE, Stuart G.; PERETTI, Silvia; POPE, Melissa. Lymphocyte-dendritic cell interactions and mucosal acquisition of SIV/HIV infection. Current Opinion in HIV and AIDS, v. 1, n. 1, p. 3-9, 2006.

UNTERHOLZNER, Leonie et al. IFI16 is an innate immune sensor for intracellular DNA. Nature immunology, v. 11, n. 11, p. 997-1004, 2010. 
USAMI, Yoshiko; WU, Yuanfei; GÖTTLINGER, Heinrich G. SERINC3 and SERINC5 restrict HIV-1 infectivity and are counteracted by Nef. Nature, v. 526, n. 7572, p. 218, 2015.

VAN DAMME, Nanette et al. The interferon-induced protein BST-2 restricts HIV-1 release and is downregulated from the cell surface by the viral Vpu protein. Cell host \& microbe, v. 3 , n. 4, p. 245-252, 2008.

VAN GELE, Mireille et al. Knockdown of myosin Va isoforms by RNAi as a tool to block melanosome transport in primary human melanocytes. Journal of Investigative Dermatology, v. 128, n. 10, p. 2474-2484, 2008.

VAN'T WOUT, Angélique B. et al. Cellular gene expression upon human immunodeficiency virus type 1 infection of CD4+-T-cell lines. Journal of virology, v. 77, n. 2, p. 1392-1402, 2003.

VÉROLLET, Christel; LE CABEC, Véronique; MARIDONNEAU-PARINI, Isabelle. HIV-1 infection of $\mathrm{T}$ lymphocytes and macrophages affects their migration via Nef. Frontiers in immunology, v. 6, 2015.

VICENTE-MANZANARES, Miguel et al. Myosin IIA/IIB restrict adhesive and protrusive signaling to generate front-back polarity in migrating cells. The Journal of cell biology, v. 193, n. 2, p. 381-396, 2011.

WANG, Jian-Hua et al. Functionally distinct transmission of human immunodeficiency virus type 1 mediated by immature and mature dendritic cells. Journal of virology, v. 81, n. 17, p. 8933-8943, 2007.

WEINBERG, J. Brice et al. Productive human immunodeficiency virus type 1 (HIV-1) infection of nonproliferating human monocytes. Journal of Experimental Medicine, v. 174, $\mathrm{n}$. 6, p. 1477-1482, 1991.

WEISSMAN, Drew et al. Both a precursor and a mature population of dendritic cells can bind HIV. However, only the mature population that expresses CD80 can pass infection to unstimulated CD4+ T cells. The Journal of Immunology, v. 155, n. 8, p. 4111-4117, 1995.

WENZEL, Jens et al. Class I myosin Myo1e regulates TLR 4-triggered macrophage spreading, chemokine release, and antigen presentation via MHC class II. European journal of immunology, v. 45, n. 1, p. 225-237, 2015.

WENZEL, Jens et al. Class I myosin Myo1e regulates TLR4-triggered macrophage spreading, chemokine release, and antigen presentation via MHC class II. European journal of immunology, v. 45, n. 1, p. 225-237, 2015.

WILEN, Craig B.; TILTON, John C.; DOMS, Robert W. HIV: cell binding and entry. Cold Spring Harbor perspectives in medicine, v. 2, n. 8, p. a006866, 2012.

WILK, Thomas; GOWEN, Brent; FULLER, Stephen D. Actin associates with the nucleocapsid domain of the human immunodeficiency virus Gag polyprotein. Journal of virology, v. 73, n. 3, p. 1931-1940, 1999.

WILLEY, R. L. et al. Human immunodeficiency virus type $1 \mathrm{Vpu}$ protein induces rapid degradation of CD4. Journal of virology, v. 66, n. 12, p. 7193-7200, 1992

WITTE, Lot et al. Langerin is a natural barrier to HIV-1 transmission by Langerhans cells. Nature medicine, v. 13, n. 3, p. 367, 2007.

WU, Li; KEWALRAMANI, Vineet N. Dendritic-cell interactions with HIV: infection and viral dissemination. Nature reviews. Immunology, v. 6, n. 11, p. 859, 2006.

WU, Li; KEWALRAMANI, Vineet N. Dendritic-cell interactions with HIV: infection and viral dissemination. Nature reviews. Immunology, v. 6, n. 11, p. 859, 2006. 
YIP, Ming Fai et al. CaMKII-mediated phosphorylation of the myosin motor Myo1c is required for insulin-stimulated GLUT4 translocation in adipocytes. Cell metabolism, v. 8, n. 5, p. 384398, 2008.

YODER, Alyson et al. HIV envelope-CXCR4 signaling activates cofilin to overcome cortical actin restriction in resting CD4 T cells. Cell, v. 134, n. 5, p. 782-792, 2008.

YORK, M. et al. A macrophage marker, Siglec-1, is increased on circulating monocytes in patients with systemic sclerosis and induced by type I interferons and toll-like receptor agonists. Arthritis Rheum. v. 56, n.3, p. 1010-20, 2007.

YU, Hyun Jae; REUTER, Morgan A.; MCDONALD, David. HIV traffics through a specialized, surface-accessible intracellular compartment during trans-infection of $\mathrm{T}$ cells by mature dendritic cells. PLoS pathogens, v. 4, n. 8, p. e1000134, 2008.

YU, Xinwei et al. Dressing up nanoparticles: a membrane wrap to induce formation of the virological synapse. ACS nano, v. 9, n. 4, p. 4182-4192, 2015.

ZHANG, Ruonan et al. SAMHD1 restricts HIV-1 replication and regulates interferon production in mouse myeloid cells. PLoS One, v. 9, n. 2, p. e89558, 2014.

ZUM BUESCHENFELDE, Christian O. Meyer et al. Regulated recruitment of MHC class II and costimulatory molecules to lipid rafts in dendritic cells. The Journal of Immunology, v. 173, n. 10, p. 6119-6124, 2004. 